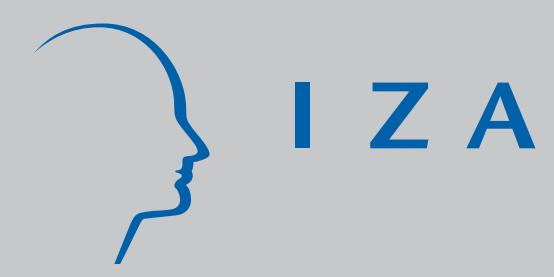

IZA DP No. 3220

Start-Ups by the Unemployed: Characteristics, Survival and Direct Employment Effects

Marco Caliendo

Alexander S. Kritikos

December 2007 


\title{
Start-Ups by the Unemployed: Characteristics, Survival and Direct Employment Effects
}

\author{
Marco Caliendo \\ $I Z A$ and $I A B$ \\ Alexander S. Kritikos \\ Hanseatic University Rostock, \\ GfA and IAB \\ Discussion Paper No. 3220 \\ December 2007 \\ IZA \\ P.O. Box 7240 \\ 53072 Bonn \\ Germany \\ Phone: +49-228-3894-0 \\ Fax: +49-228-3894-180 \\ E-mail: iza@iza.org
}

\begin{abstract}
Any opinions expressed here are those of the author(s) and not those of the institute. Research disseminated by IZA may include views on policy, but the institute itself takes no institutional policy positions.

The Institute for the Study of Labor (IZA) in Bonn is a local and virtual international research center and a place of communication between science, politics and business. IZA is an independent nonprofit company supported by Deutsche Post World Net. The center is associated with the University of Bonn and offers a stimulating research environment through its research networks, research support, and visitors and doctoral programs. IZA engages in (i) original and internationally competitive research in all fields of labor economics, (ii) development of policy concepts, and (iii) dissemination of research results and concepts to the interested public.
\end{abstract}

IZA Discussion Papers often represent preliminary work and are circulated to encourage discussion. Citation of such a paper should account for its provisional character. A revised version may be available directly from the author. 


\section{ABSTRACT \\ Start-Ups by the Unemployed: Characteristics, Survival and Direct Employment Effects}

Fostering and supporting start-up businesses by unemployed persons has become an increasingly important issue in many European countries. These new ventures are being supported by various governmental programs. Potential benefits include not only the end of unemployment for the new entrepreneur but also some further positive effects, e.g., direct job creation. However, it is often feared that the previously unemployed lack the basic qualifications to become entrepreneurs. Empirical evidence on skill-composition, direct job creation and other key variables is rather scarce, largely because of inadequate data availability. We base our analysis on a unique and very informative survey data containing a representative sample of over 3,100 start-ups founded by unemployed persons in Germany. Individuals were subsidized under two different schemes, and we are able to draw on extensive pre- and post-founding information concerning the characteristics of the business (start-up capital, industry, etc.) and of the business founders (education, motivation, preparation, etc.). We find that formerly unemployed founders are motivated by push and pull factors. Using a proportional hazard duration model with unobserved heterogeneity allows us to analyze the characteristics which drive success of the businesses. While survival rates 2.5 years after business founding are quite high (around 70\%) for both programs and genders, the characteristics of the newly developed businesses are heterogeneous.

JEL Classification: J68, M13

Keywords: $\quad$ start-up subsidies, self-employment, unemployment, direct employment effects, survival

Corresponding author:

Marco Caliendo

IZA

P.O. Box 7240

D-53072 Bonn

Germany

E-mail: caliendo@iza.org 


\section{Introduction}

Fostering and supporting start-up businesses set up by unemployed persons has become an increasingly important issue in many European countries. These new ventures are being supported by various governmental programs. Potential benefits include not only the end of unemployment for the new entrepreneur but also some further positive effects, e.g., direct further job creation. ${ }^{1}$ However, it is often feared that the formerly unemployed lack the basic qualifications to become entrepreneurs.

Empirical evidence on the characteristics of previously unemployed business founders, their survival rates, direct job creation and other key variables is rather scarce and is usually based on small datasets. ${ }^{2}$ One possible reason is that start-up subsidies for the unemployed are usually only a small component in the active labour market policies of individual countries. However, in Germany things have changed radically in the last decade. While the Federal Employment Agency (FEA) funded only 37,000 business start-ups by formerly unemployed individuals in 1994, the number was in excess of 250,000 in 2005 (of which approximately 160,000 were in West Germany). This increase was, inter alia, driven by a new programme known as the 'start-up subsidy' (SUS, Existenzgründungszuschuss), which was introduced in 2003 as part of the 'Hartz-reforms'. ${ }^{3}$ For a period of more than three-and-a-half years, unemployed individuals could choose between two programmes supporting their decision to become self-employed: the 'start-up subsidy' and the 'bridging allowance' (BA, Überbrückungsgeld), the latter having been implemented earlier, in the late 1980s. ${ }^{4}$ Both programmes differ in their design, the most important difference being in respect of the amount and duration of the subsidy. While the BA pays recipients the same amount that they would have received as unemployment benefits for a period of six months (plus a lump sum of roughly $70 \%$ of the same, to cover social security contributions), the SUS runs for three years, paying a lump sum of $€ 600 /$ month for the first year, $€ 360 /$ month for the second, and $€ 240 /$ month for the third.

This paper investigates what kind of businesses were created by those who took advantage of one of the two programmes. Based on a representative data-set of West German start-ups of unemployed persons, which were subsidized by these two schemes, we are not only able to shed light on the characteristics of the business founders, but also to describe the types of

\footnotetext{
${ }^{1}$ For a more general discussion on the value of entrepreneurship and a recent survey on empirical evidence, see van Praag and Versloot (2007). Blanchflower and Oswald (2007) report another possible benefit on the individual level. Based on cross-country evidence they show that self-employed individuals have a higher job- and life-satisfaction (when compared to similar employees).

${ }^{2}$ For some earlier evidence in the European context, see, e.g., Storey and Jones (1987), Evans and Leighton (1990), Storey (1991), Audretsch and Vivarelli (1995), Hinz and Jungbauer-Gans (1999), Pfeiffer and Reize (2000), and Andersson and Wadensjö (2006).

${ }^{3}$ The 'Hartz-reforms' were (and still are) a large reform of the German labour market, adjusting active and passive labour market policies. Within the reform process, resources were shifted away from traditional active labour market policy programmes - like job creation schemes and vocational training programmes - to more innovative measures like start-up subsidies and short training programs (see Caliendo and Steiner, 2005, for an overview).

${ }^{4}$ Both programs were replaced in August 2006 by a single new program - the new start-up subsidy programme (Gründungszuschuss)—which will not be analyzed here.
} 
businesses started, the associated direct job creation after 2.5 years, and the resulting personal incomes of business founders. Wherever possible, we also compare their characteristics with those persons who started new businesses but were not previously unemployed before doing so (hereafter called "other start-ups"). ${ }^{5}$ While survival rates 2.5 years after business founding are quite high (and similar) for both programs, employment effects, income, and investment sizes differ significantly between the two support schemes: the two programmes attracted very different types of individuals, resulting in very different types of businesses. It is fair to say that participants in the BA were relatively more qualified and created larger businesses.

Compared to earlier studies focusing on development of start-ups, we have been able to collect a rich panel data set, making our analysis unique. Most yearly surveys on general startup activities (such as the General/Regional Entrepreneurship Monitor(s), the KfW start-up monitor or the micro-census) and previous studies on start-ups by unemployed persons (such as the articles of Hinz and Jungbauer-Gans (1999) or of Pfeiffer and Reize (2000)) had, and have, access to a relatively small number of observations (in terms of the absolute number of start-ups by unemployed persons) and only to a few basic socio-demographic and economic variables. In contrast to this, we put together a comprehensive series of data combining administrative data with survey data. This allows us to investigate the development of the businesses over the first 2.5 years, and to analyze reasons for their survival. Moreover, as we draw on a representative sample of start-ups by unemployed persons, we are able to systematically compare the results of the two support schemes, BA and SUS, and to derive some general conclusions about personal and business-related characteristics of previously unemployed entrepreneurs.

The rest of the paper is organized as follows: Section 2 presents the main characteristics of the bridging allowance and of the start-up subsidy. Moreover, we provide a brief general overview of self-employment trends in Germany, to the extent possible, given that the available data with respect to business founders is rather limited in Germany. Section 3 discusses the characteristics of the formerly unemployed business founders and describes the businesses they created. In Section 4 we analyze the survival rates and discuss personal and business-related characteristics that drive success and failure. We also discuss direct employment effects, growth of personal incomes and the possible occurrence of deadweight losses and displacement effects. Section 5 summarizes the findings and presents the conclusions.

Both programmes seem to be quite successful, though the results for the SUS have to be treated with some caution since they are only preliminary, as we will explain later on. The SUS attracted groups which had been under-represented not only in the already existing support scheme (the BA) but also among the group of self-employed persons in general. Even though these new target groups created rather small businesses - mostly without any further employees and with no or only little capital — the labour market attachment of the participating individuals was generally raised while the personal income was increased for the majority of the male

\footnotetext{
${ }^{5}$ As the labour market situation and the development of new start-ups differs between West and East Germany (due to the economic transformation of East-Germany), we focus on West Germany in this paper. For previous evidence on the differing development, see for instance Fritsch (2004) and Kronthaler (2005).
} 
SUS founders. The BA, on the other hand, yielded the double dividend the policy-makers were hoping for. Survival rates of businesses are high, personal incomes of the majority of all start-up entrepreneurs have gone up, and a remarkable number of additional jobs have been created. Altogether, we conclude that there seems to be room for two different programmes supporting self-employment. Apparently, the second program - the SUS - was designed in a way that provides sufficient safety to target groups that were (and still are) under-represented among the self-employed.

\section{Self-Employment Trends and Start-Up Subsidies in Germany}

In this section, we provide a short overview over the main features of the two programmes, the number of entries into the two programmes during the last 20 years, and a brief review of some figures with respect to general start-up activities and recent trends in the area of selfemployment.

\subsection{Start-Up Subsidies: Programme Features and Number of Entries}

From 1986 to 2002, the bridging allowance was the only programme providing support to unemployed individuals who wanted to start their own business. Its main goal was to cover basic costs of living and social security contributions during the initial stages of self-employment, when the business might not be able to yield adequate income. Usually, self-employed persons need financial support during the start-up period because of several reasons. ${ }^{6}$ They need to fund some initial investment as well as the costs of living during the gestation period. Besides, they often have to develop their entrepreneurial skills and knowledge because of having moved from employment or unemployment to self-employment.

The BA supported the first six months of self-employment by providing the same amount that the recipient would have received in case of unemployment. Since the unemployment scheme also covered social security contributions, including health and retirement insurance, etc., an additional lump sum for social security was granted, equal to approximately $70 \%$ of the unemployment support. Unemployed people were entitled to BA, conditional on their business plan being approved externally, usually by the local chamber of commerce. Thus, approval of an individual's application did not depend on the local labour office. ${ }^{7}$

In January 2003, SUS, the second programme, was launched to support unemployed people starting new businesses. The main goal of SUS was to provide security during the initial phase of

\footnotetext{
${ }^{6}$ See, e.g., Blanchflower and Oswald, 1998, and Johannson, 2000, on the importance of start-up capital and capital constraints for becoming self-employed.

${ }^{7}$ Access to this program was eased in 2002. Until 2002, persons had to stay unemployed for a minimum of one month before they were allowed to apply for the BA. From 2002 onwards, one may apply for the BA even on the first day of unemployment.
} 
self-employment. It focused on provision of social security for the newly self-employed persons, not for the first six months but for the first three years. The support comprises a lump sum payment of $€ 600 /$ month in the first year, $€ 360 /$ month in the second year and $€ 240 /$ month in the third year, with the condition that support in the second and third year was granted only if income of the entrepreneur did not exceed $€ 25,000$ in the previous year. In contrast to the BA, SUS recipients were obligated to contribute to the statutory pension insurance fund, but could claim a reduced rate for national health insurance (Koch and Wießner, 2003). When the SUS was introduced in 2003, applicants did not have to submit business plans for prior approval, but were required to do so after November 2004, as was already the case with the BA. See Table 1 for more details on both programmes.

\section{INSERT TABLE 1 ABOUT HERE}

Hence, between January 2003 and July 2006, unemployed individuals could freely choose between the two programmes to support their new businesses. One scheme was financing the first six months of self-employment by providing what the individual would have received in unemployment benefits (BA), and the other offered a fixed, yet declining, amount for the first three years of self-employment with the risk of losing the support if the income grew beyond specified limits (SUS). In this institutional framework, the BA would be the rational choice if the unemployment benefits are fairly high or if the entrepreneur expects to generate an income higher than $€ 25,000$ in the first year.

\section{InsERT Figure 1 ABOUt HeRE}

The number of beneficiaries of the two programmes during the last two decades makes it clear that support measures towards self-employment have gathered increasing importance in Germany's active labour market policy (ALMP). While the Federal Employment Agency funded only 5,600 persons under the BA in 1986, the number increased to 37,000 business start-ups in 1994, and further to 125,000 in 2002 , the year before the second scheme was introduced (see Figure 1).

In 2003, the number of start-ups financed under either of the two schemes doubled to more than 250,000; 159,000 individuals used the BA route and another 97,000 applied for the SUS. Due to some changes in the eligibility conditions introduced between 2004 and 2005, the number of total start-ups under the two programmes peaked in 2004; the 350,000 entries were almost equally divided between the two schemes. In that year, almost $10 \%$ of Germany's registered unemployed persons participated in the programmes; assistance provided under the two schemes accounted for $17 \%$ of the total spending on ALMP. That made these two programmes together, in terms of participants and spending, the most important of the year. In 2005, the number of entries was almost identical to 2003. In the first seven months of 2006, another 100,000 set up businesses with support from the BA and 43,000 from the SUS. In line with a general policy to 
reduce the number of active labour market programmes (see, e.g., Eichhorst and Zimmermann, 2007), the two programmes were replaced in August 2006 by a single new program - the new start-up subsidy (Gründungszuschuss) — which is not analyzed here.

\subsection{Self-Employment Trends}

In order to be able to compare in later sections the characteristics of businesses set-up by unemployed persons with other start-ups, we provide in this subsection a short review of some general trends. It has to be emphasized, however, that this data, such as the number of yearly start-ups, the share of start-ups by previously unemployed among all new businesses, and their relevant characteristics, does not provide exact information in Germany. ${ }^{8}$

Basic data of yearly start-ups are provided by the "Institute for Small Business research" (Institut für Mittelstandsforschung, IfM, 2007). The IfM carries out a complete annual inventory count in the area of the "industrial economy" which covers about $80 \%$ of all start-ups and excludes only "professional persons" (for instance lawyers, architects, etc.). For the year 2003, the first year of the SUS, the IfM observed that in comparison to 2002, there was an increase from 452,000 to 509,000 in the number of start-ups, and in 2004, the number further increased to 573,000 start-ups. In 2005, the number of start-ups dropped to 501,000 (for all data see Institut für Mittelstandsforschung, 2007). This observation reveals that there was a significant increase in the number of start-ups, in comparison to the year before the SUS was launched. Moreover, between 2003 and 2005, there was a parallel growth in the total number of start-ups as well as in the number of start-ups by unemployed persons. Without having information about the precise share of start-ups by unemployed persons within the IfM data-set, this observation indicates, to a certain extent, that the increase in the total number of start-ups was driven by start-ups by unemployed persons. ${ }^{9}$

Focusing on the socio-demographic characteristics of founders of start-ups, our analysis in the next section requires an overview of three more variables, namely gender, education, and age. Information about the first variable, gender, can be found in the micro-census (Mikrozensus), which is a representative $1 \%$ sample drawn every year, in early spring, from the total population of Germany (see, e.g., Piorkowsky, 2006). The micro-census reveals that start-ups are predominantly initiated by men. Between 1996 and 2003, the share of men in total start-ups was more or less unchanged at around $72 \%$ (leading to similar shares among the total number of self-employed, too). With the new support scheme SUS, the ratio slightly shifted in favour of

\footnotetext{
${ }^{8}$ All existing statistics suffer either from the problem of under- or over-estimation of the yearly number of start-ups. Moreover, almost none of the sources is able to reveal how many of the founders started businesses out of unemployment; that is why we are able to present only some broad trends. For further details see Fritsch, Grotz, Brixy, Niese, and Otto (2002) or Kritikos and Kahle (2006).

${ }^{9}$ Caliendo, Fossen, and Kritikos (2006) analyze - based on the German Socio-Economic Panel (SOEP) - the risk-attitudes of nascent entrepreneurs in 2004 and show that during this period about every second person started self-employment out of unemployment. However, since the data cover only 150 business founders, it is too small for an annual analysis of whether the growth in start-ups by unemployed persons had had a direct effect on the number of self-employed.
} 
female start-ups; in the subsequent two years, the share of female start-ups increased from $28 \%$ to about $30 \% .^{10}$

Education and age of business founders are two variables which are observed in the startup monitor of the state-owned bank KfW (Kreditanstalt für Wiederaufbau), which provides a yearly report on start-ups, and the German Socio-Economic Panel (SOEP), a representative panel survey containing information about the socio-economic situation of 22,000 individuals living in 12,000 households in Germany. Besides, we can also extract some information from two earlier studies of Hinz and Jungbauer-Gans (1999) and Pfeiffer and Reize (2000), which compared start-ups by unemployed persons (then supported by the BA) with other start-ups with respect to education.

All sources have observed the same tendencies, with respect to education. Hinz and JungbauerGans (1999) report that founders of start-ups are -irrespective of their previous employment status - highly educated. A little less than $50 \%$ of the observed business founders had, for instance, general or specialized secondary schooling. The KfW report and the SOEP panel data have observed similar shares of the highly educated in start-ups and have emphasized that the share of those who have finished upper secondary schooling and/or tertiary education among business founders is higher than in the total population of employed and unemployed persons (see Kreditanstalt für Wiederaufbau (2006) and Caliendo, Fossen, and Kritikos (2006) for the SOEP-data). ${ }^{11}$

With respect to the age of the founders of start-ups both surveys, the KfW start-up monitor and the SOEP, observe a u-shaped distribution over the last few years; the highest share among all founders can be found in age group between 30 and 40 years, while there are decreasing shares in both directions (between 14 and 29 years as well as above 40 years). It is also interesting to note that Pfeiffer and Reize (2000), whose sample systematically excludes the smaller businesses, also observe a u-shaped distribution with its peak between 30 and 35 years. In section 3.2 we will compare the distribution of these variables for both support schemes and relate the results with the general trends observed here.

\section{INSERT Figure 2 ABOUt HERE}

Increasing start-up activities can have a lasting impact on the economy only if there is a positive balance between entries into and exits from self-employment; i.e. when the total number of self-employed persons increases. Information about the growth in the number of self-employed persons can also be derived from the micro-census. It shows that there has indeed been a constant increase in the number of self-employed persons in Germany during this period (see Figure 2).

\footnotetext{
${ }^{10}$ Similar trends were also observed in smaller samples, see Hinz and Jungbauer-Gans (1999), Kreditanstalt für Wiederaufbau (2006) or Wagner (2007). However, only the micro-census - due to its larger sample size-allows one to point out the change in the share of female start-ups.

${ }^{11}$ The micro-census reveals a similar trend among the stock of self-employed persons: share of those having finished upper secondary schooling among self-employed persons is around $41 \%$, whereas among all employed persons it is only $29 \%$, c.f. Statistisches Bundesamt (2005).
} 
Three further observations are particularly worth mentioning: 1) In the year 2005, for the first time, the number of self-employed persons was estimated at over four million; 2) During the last 15 years, the total number of self-employed persons has increased by one million. ${ }^{12}$ 3) This increase of one million in the number of self-employed persons is almost exclusively accounted for by persons who became self-employed without creating any further jobs. As the micro-census reveals, the number of solo-entrepreneurs increased during the last 15 years (1991-2005) from 1.4 to 2.3 million, while the number of self-employed persons employing some others remained nearly constant during the same period (see Figure 2). ${ }^{13}$

\section{Data and Characteristics of the Business Founders}

\subsection{Data}

We use a unique data set which originates from a large evaluation project for the Federal Ministry of Labor and Social Affairs (for details see Caliendo, Steiner, and Baumgartner, 2006). The data consists of a random sample of approximately 3,100 participants who became self-employed in West Germany in the third quarter of 2003, with support under either SUS or BA; approximately 1,500 participants used the SUS and 1,600 the BA. By combining administrative data from the FEA with survey data, we are able to draw conclusions for a representative sample of persons who were unemployed and became business founders. For the administrative part we use data based on the 'Integrated Labour Market Biographies' (ILMB, Integrierte Erwerbs-Biographien) of the FEA, containing relevant register data, e.g., socio-demographic variables or the labour market history of individuals.

The data is enriched with computer-assisted telephone interviews; business founders were surveyed twice with a standardized questionnaire. The first interviews took place in January/February 2005 and the second round in January/February 2006. Most importantly, individuals were questioned in detail about certain characteristics of their businesses, including start-up capital and industry, and were also asked to provide details about their preparation, motivation and previous knowledge and experience. At the time of the second interview, individuals had run the business for at least 2.5 years and were asked about their employment status, the number of employees and their personal incomes. We will discuss the characteristics of the business founders in Section 3.2, before we describe the motivation, preparation and other characteristics of the businesses in Section 3.3.

What should be kept in mind at this stage is that a majority of persons utilizing the SUS were still receiving a subsidy at the end of our observation period, i.e., the time of the second interview.

\footnotetext{
${ }^{12}$ In 1991, the same report (micro-census) had estimated about three million persons in self-employment.

${ }^{13}$ This tendency is expected to be be sustained in the future: the micro-census observed that only $20 \%$ of all start-ups in the year 2005 employed other persons, whereas in $199630 \%$ of them offered jobs to others (for all figures cf. Piorkowsky, 2006).
} 
Only those who had exceeded the income limit of $€ 25,000$ in the previous year had lost access to the subsidy. Clearly, from an evaluator's point of view, it would be nice to have an observation window which covers the time after the subsidy has completely run out. However, we argue that the amount of $€ 240$, received in the third year, is quite small. Moreover, it had a mandatory use, as the participants were obliged to pay the money into the social security system. Thus, the subsidy only had an indirect effect on the income of the observed participants. Therefore, we believe that our analysis gives a good indication of the situation without the subsidy.

\subsection{Characteristics of the Business Founders}

Table 2 contains sample means of selected variables describing the characteristics of the business founders. In order to reveal differences between participants under the two programs and gender differences within a program, we add results from a t-test of mean equality between the four groups. We report $p$-values, which refer to differences between men and women in BA $\left(p_{1}\right)$, men and women in SUS $\left(p_{2}\right)$, men in BA and SUS $\left(p_{3}\right)$ as well as women in BA and SUS $\left(p_{4}\right)$. The $p$-value refers to the significance level below which the hypothesis of mean equality can be rejected, e.g., a value of 0.05 shows that means are not equal at a significance level of $5 \%$.

\section{INSERT TABLE 2 ABOUT HERE}

A first glance at the number of observations reveals clear gender differences between both programmes. While the male-female ratio is about 3:1 for BA - thus very similar to the ratio in the overall population of business founders, and of self-employed persons - we observed a very different ratio, approximately 1:1, for the SUS. The results of the t-tests (columns 5-8) also reveal that the marital status clearly varies between genders and programmes. While the majority of the male business founders who used the BA were married, this is true for only $43 \%$ of the women. On the other hand, nearly $60 \%$ of the female participants in SUS are married, possibly indicating that these women are using self-employment mainly to generate additional income for the household. Women in SUS also have significantly more children (see $p_{4}$ ) than their counterparts in BA, and are significantly reluctant to work full time.

Health constraints do not play a major role; the majority of participants indicates to have no such constraints. Looking at the age distribution once again shows some interesting differences between men and women in SUS $\left(p_{2}\right)$ and men in SUS and BA $\left(p_{3}\right)$. Most of the start-ups are aged between 30 and 39 years (around 40\%), which is similar to the overall age composition of business founders. One exception was found in the SUS, where we observed a significantly higher share of younger male individuals. The mean age in this group is 37.7 years, whereas it is 39 for other groups.

Further differences emerge when one looks at qualifications (see Table 3). Comparing the participants' qualifications by the highest school degree or the variable 'job qualifications'—which 
is an assessment by the case manager in the local labour office - we see that BA participants are significantly more qualified. For example, the share of individuals who had completed upper general or specialized secondary schooling is high among participants in BA-it is almost the same as in the overall start-up trend (44\% of men / $56 \%$ of women, see Hinz and JungbauerGans, 1999). For SUS participants it was much lower (29\% of men / $35 \%$ of women). Job qualifications show a similar picture. Here, $24 \%$ of the male and $33 \%$ of the female participants in BA are ranked as highly qualified, whereas this is true for only $12 \%$ (17\%) of the male (female) participants in SUS.

\section{INSERT TABLE 3 ABOUT HERE}

Based on the above, it is not surprising that participants in BA also have a more favourable labour market history. Compared to SUS, fewer of them faced long-term unemployment before starting a business (Table 3). They also have higher and longer claims for unemployment benefits. The differences are substantial: e.g., male BA recipients received unemployment support amounting to $€ 38.80 /$ day before starting a programme, whereas SUS recipients received only $€ 23.30$ /day. It is also worth mentioning that the remaining period of benefit entitlement differed significantly between the two groups - approximately seven months for BA recipients and five for SUS recipients.

Given the relatively stable popularity and participant structure of the BA programme, even after introduction of the SUS, one can argue that the SUS attracted a different 'clientele' for self-employment. In general, it can be stated that participants in SUS are less qualified (when compared to BA participants), and that this programme is more frequently used by women and younger men.

\subsection{Characteristics and Preparation of the Start-Ups}

After having highlighted the differences between the business founders, we now investigate whether there are differences in the types of businesses set-up, the motives to do so, and the preparations undertaken.

\section{INSERT TABLE 4 ABOUT HERE}

Table 4 highlights some important pre-start-up characteristics. Individuals were asked whether they had previous working experience in the sector in which they aimed to start their business. It becomes evident that nearly three quarters of the participants who used the BA had experience of regular employment in the same industry and there were no differences between men an women. On the other hand, the share of men and women in SUS with experience of regular work in the same industry is significantly lower. The latter individuals, however, reported having significantly higher experience of having handled similar work in their spare time, 
indicating that some of these start-ups were probably moonlighting before they decided to run an official business. Moreover, around $13 \%$ of all individuals start their business without any relevant experience; one significant exception here are women in SUS, where nearly $20 \%$ of the individuals started without any relevant experience. This observation might be interpreted in several ways. Persons launching a business without any previous experience made their decision i) either because they had no choice since they were running out of entitlement for unemployment support, or ii) because the business they started was relatively simple, needing no special competencies.

Fewer differences emerged when individuals were specifically asked what kind of preparation they undertook. In general, participants in BA used more preparation than participants in SUS, and the main source of support was coaches and consultants.

When focusing on the motivation for becoming self-employed, three motives are mentioned most often, namely i) "termination of unemployment", ii) "being my own boss", and iii) "had first customers", where the differences in these motives between BA and SUS are smaller than expected. Clearly, the central "push" motive - termination of unemployment - is significantly more important for individuals in SUS, while the typical "pull" motive- "being my own boss" is equally distributed between men (around 55\%) and women (around 47\%) in BA and SUS. Additionally, the third main motive - "I had first customers" - also a "pull" motive, is reported by about $60 \%$ of the individuals, while men in SUS are outliers with a share of $65 \%$. This observation is certainly important when we compare it with earlier studies. For instance, Evans and Leighton (1990), Meager (1992), or Pfeiffer and Reize (2000) differentiated between "push" or "necessity" start-ups, i.e., those initiated by unemployed persons, and "opportunity" or "pull" start-ups in case the business founder was regularly employed (or elsewhere) before. Our analysis makes clear that this differentiation does not hold anymore. Today, start-ups by unemployed persons are guided by both motives: they want to, and they have to become self-employed at the same time. Evidence for this new development can directly be found in our survey. We allowed multiple answers to questions on the motives for becoming self-employed and found out that little less than $40 \%$ of the BA-business founders, and even more than $40 \%$ of the SUS start-ups declared that both push and pull motives were the reason for their decision (see again Table 4).

\section{INSERT TABLE 5 ABOUt HERE}

When looking at the industries in which the start-ups enter (upper half of Table 5), it becomes obvious that there are more gender than programme differences. For example, men in SUS and BA are equally likely to opt for a start-up in the construction sector (around 12\%), whereas only $2 \%$ of the women choose this sector; $60 \%$ of the females in BA and SUS chose "other services" while only $30 \%$ of the males did so.

Strong gender and programme differences were observed when looking at the amount of start-up capital used. Men clearly invest more than women and participants in BA invest more 
than participants in SUS. About $50 \%$ of the individuals starting with SUS claimed that they did not use any start-up capital at all. While this is true for only approximately $35 \%$ of the business founders with BA, the differences get even sharper when concentrating on start-ups with capital of more than $10,000 € .38 \%$ of the males and $29 \%$ of the females in BA began with a capital of more than $10,000 €$ whereas only $17 \% / 11 \%$ of the men/women in SUS did so.

Further interesting results can be obtained when looking at the averages of invested capital and the share of own capital founders used for starting their businesses. Male business founders with BA invested the highest amounts (almost 18,000€), used more of their own capital (little more than 13,000€), and asked for more external financing (little less than 5,000€), than the remaining three groups. They were followed by female founders with BA (with a total average investment of 12,600€, own capital of 8,700€ and external financing of little less than 4,000€). Average investments of male/female SUS business founders were about the half of their BA counterparts'.

In all, it is remarkable that the average share of own capital used to start the businesses is above $70 \% .{ }^{14}$ With respect to female BA founders, two characteristics should be emphasized: they invested more than the SUS male founders and they had (little less than 70\%) the lowest share of own capital.

We further asked whether business founders needed capital infusion for a second time after the start-up period. Between $30 \%$ and $40 \%$ of the persons answered yes - most often to finance further growth of their business (in more than $60 \%$ of the cases) or for certain projects (in little less than $30 \%$ of the cases). It is remarkable again that among BA participants in particular, female start-ups had invested significantly more often once again in their businesses than male start-ups in BA and their female counterparts in SUS.

\section{Survival, Income and Direct Employment Effects}

\subsection{Survival}

The most obvious index to measure the success of start-ups is their survival rate. Figure 3 shows the survival rates, differentiated by gender and programme, between the month of business foundation (third quarter of 2003) and the time of the second interview in January/February 2006. Remember that the support from BA runs only for six months; so we were able to observe individuals without receiving the subsidy for about two years. Individuals making use of the SUS, who earned not more than $25.000 €$ in the previous year and were still self-employed, were mostly receiving the third year's subsidy (240€ per month) at the time of the interview. Hence, when comparing the survival rates of the two support schemes, it is not surprising that the

\footnotetext{
${ }^{14}$ Similar trends were observed by Levenson and Willard (2000) in US data and by Parker and van Praag (2006) in Dutch data.
} 
survival rates were higher for individuals in SUS, irrespective of gender. It also becomes obvious that in the first few months after start-up (when both programmes were still running), there are no significant differences in the survival rates between the two programmes. However, shortly after the BA runs out some individuals have to end their business, and slightly lower survival rates emerge for the $\mathrm{BA}$.

\section{InsERT Figure 3 ABOUt HERE}

Table 6 shows the employment status of the individuals at the end of our observation period and reveals that the survival rates range between $74.4 \%$ for women in SUS and $68.3 \%$ for women in BA. In this context, the important fact is that these survival rates are similar to earlier observations, when there was a significantly lower share of start-ups by unemployed persons. Previous studies (when the number of start-ups funded by the BA program was below 100.000 persons per year) recorded survival rates of $90 \%$ after one year (c.f. Pfeiffer and Reize, 2000), $80 \%$ after two years (Hinz and Jungbauer-Gans (1999)) and 70\% after 3 years (c.f. Wießner, 2001), which are quite similar to the survival rates in this paper. ${ }^{15}$ Moreover, the first two studies found no significant differences between survival rates of start-ups by unemployed persons and other start-ups.

\section{INSERT TABLE 6 ABOUt HeRE}

Table 6 highlights two more things of importance. First, even though the survival rates are the highest for men/women in SUS, a higher share of men in BA reports to be self-employed at the second interview. These individuals have failed during the observation period but re-started their business. To distinguish these cases, Table 6 also contains the share of individuals who were permanently self-employed during the observation period. A second thing to note is that not every closed business is a failure, per-se, at least when the goal of the support schemes is to enable individuals to return to working lives. In this context it should be emphasized that a significant percentage of individuals found regular employment in due course (i.e. after setting up their businesses), so that in all the four subgroups $81 \%$ to $87 \%$ were either self-employed or had found regular employment. Only $8 \%$ to $15 \%$ of the individuals had again been registered as unemployed, at the time of the interview.

In order to be able to analyse the factors which drive survival in self-employment, we use a duration model.

The Survival Model: Duration models are well suited to analyze the determinants of survival in self-employment (or any other labour market state), since they explicitly take the data specificity into account. In our case we have a sample of individuals $i=1, \ldots, N$ who have

\footnotetext{
${ }^{15}$ It should also be mentioned that in ten OECD countries failure rates of newly founded businesses, after two years, are between 20 and 40 per cent (see Bartelsmann, Scarpetta, and Schivardi, 2005).
} 
entered self-employment at time $t=0$. We observe for each individual $i$ the time $T_{i}$ spent in self-employment. If individuals remain self-employed for the whole observation period, the data are right-censored. That is, in the last moment observed, several spells have finished, while others continue (Table 6 has shown that nearly $70 \%$ of our sample remain self-employed over the whole observation period). The failure function is given by:

$$
P(T \leq t)=F(t)
$$

and the survivor function is:

$$
P(T>t)=1-F(t) \equiv S(t)
$$

We assume that the hazard rate for person $i$ at time $t>0$ takes the proportional hazard form

$$
\lambda_{i t}=\lambda_{0} \cdot \exp \left[X_{i t}^{\prime} \beta\right]
$$

where $\lambda_{0}(t)$ is the base-line hazard at time $t, X_{i t}$ is the vector of (possibly time-variant) explanatory variables for individual $i$, and $\beta$ is the vector of parameters which we are finally interested in. In our data, we only observe the month of the transitions, but not the exact date (within a month). In principle, the transitions could occur at any time during the observed intervals. For the later estimation, we assume that transitions can only occur at the boundaries of the intervals (see, e.g., Narendranathan and Stewart, 1993, for a similar apporach). For the discrete time model, the probability of a spell being completed by time (interval) $j+1^{16}$, given that it was still continuing at interval $j$, is given by (see, e.g., Meyer, 1990):

$$
h_{i j}=P\left(J_{i}<j+1 \mid J_{i} \geq j\right)=F\left(\gamma(j)+X_{i}(j)^{\prime} \beta\right)
$$

where $F(\cdot)$ is the Extreme Value cumulative distribution function and $\gamma(j)$ captures additive duration dependence (specific for each $j$ ). This leads to:

$$
h_{j}\left(X_{i j}\right)=1-\exp \left(-\exp \left(X_{i j}^{\prime} \beta+\gamma_{j}\right)\right)
$$

If one defines an indicator variable $c_{i}$ equal to 1 if the spell is completed at $j$, and 0 if it is censored, the contribution of the ith individual to the log-likelihood is given by (see Carrasco, 1999):

$$
L_{i}=c_{i}\left(\sum_{j=1}^{J_{i}-1} \log \left[1-h_{i}(j)\right]+\log h_{i}\left(T_{i}\right)\right)+\left(1-c_{i}\right)\left(\sum_{j=1}^{J_{i}} \log \left[1-h_{i}(j)\right]\right)
$$

In order to account for unobserved heterogeneity between individuals, we incorporate a Gamma distributed random variable $\epsilon_{i}$ with unit mean and variance $\sigma^{2} \equiv \nu$, such that the hazard function corresponding to (5) is:

\footnotetext{
${ }^{16}$ In order to distinguish the continuous time case from the discrete time case, for the latter we use time index $j$.
} 


$$
h_{j}\left(X_{i j}\right)=1-\exp \left(-\exp \left(X_{i j}^{\prime} \beta+\gamma_{j}+\log \left(\epsilon_{i}\right)\right)\right) .
$$

Results: We estimated the model separately for men and women in the two programmes; Table 7 contains the results. ${ }^{17}$ In order to account for duration dependence, we tested flexible parametric specifications for the baseline hazard. Since the results were not sensitive to specification choice, we present only the quadratic specification. ${ }^{18}$

\section{INSERT TABLE 7 ABOUT HERE}

Our data allows a comprehensive analysis of variables having an impact on the survival of the businesses, such as the labour market history and various socio-demographic characteristics of the persons as well as their motivations to launch a business and previous working experience. Additionally, we also have information on their preparations before starting the business, the amounts of capital invested, and the chosen industry sector. A general result of the analysis also needs to be emphasized. As the two support schemes attracted different target groups, we also find differing effects between the businesses which were started with either one of the programmes.

Beginning with the socio-demographic characteristics, we find that in all groups (except for the male start-ups making use of the BA) the variable "age" had a significant impact on survival: taking the age group "18-29 years" as the reference category, we see that individuals in the next age group "30-39 years" (the group with the most participants) have a significantly lower failure probability. The same positive impact of higher age holds for the SUS, even in the older age groups. This outcome might be interpreted to suggest that it seems to be important for the survival of a self-employed person to have gained some working experience before becoming self-employed. That may be the reason why older persons are more successful than persons in the younger groups.

Turning to formal education - often believed to be essential for self-employment success (c.f. e.g., Cooper, Gimeno-Gascon, and Woo (1994) or Parker and van Praag (2006)) — we found the expected correlations only in case of SUS: under this scheme, survival rates increase with a higher school degree. This is important insofar as the SUS attracted more persons with lower school degrees than the BA. For BA start-ups, the school degree had no impact on the survival of the business, though another negative impact needs to be mentioned. Immigrants to Germany (often accentuated because of start-up rates above average within the population in Germany) also showed a significantly higher failure rate of businesses.

The labour market history plays no role for the BA start-ups. This is interesting, as it is usually expected that unemployment duration has a negative impact on survival. The hypothesis

\footnotetext{
${ }^{17}$ The estimations are done using the pgmhaz8 Stata module.

${ }^{18}$ Full estimation results are available on request by the authors.
} 
behind this expectation is that the longer a person has been unemployed, the more is his/her human capital depreciated and the harder it is for him/her to re-enter any kind of employment. As a consequence, it is expected that the survival probability of the self-employed decreases as the unemployment duration increases. We found the expected impact of this variable for male SUS start-ups: there was a significantly positive correlation between the amount of remaining unemployment benefit entitlements in months and the survival rate in self-employment.

With respect to business characteristics we focus on invested capital and on the chosen industry sector. In particular, the amount of the invested capital has a highly significant impact on survival rates: against the base-line category "no capital", females who invested more than $2,500 €$ and males who invested more than $10,000 €$ have significantly higher survival rates. This observation indicates that start-ups with higher amounts of capital have a long-term perspective of their business and probably have planned their businesses more carefully. ${ }^{19}$

Besides, the chosen industry sectors also have an impact on survival rates, though it is different for the two support schemes. Male BA start-ups choosing craft and construction sectors and male SUS start-ups in the IT-sector (all three sectors are male dominated) have significantly higher survival rates compared to the base-category of "other industries". In particular the positive impact in the construction sector should be highlighted: it seems that the recently observed positive development of this sector (after high failure rates in previous years) also increased the survival probabilities of new businesses. Female start-ups (being supported by the BA) who choose to start businesses in the retail sector had relatively lower survival rates. This concurs with the view of commercial banks, which have this sector 'redlined', i.e., applications of start-up loans for retail ventures are often rejected.

Last but not the least, in entrepreneurship research it is believed that the decisive variables for success and failure are often found in the start-up's motivation, their working experience and the preparation and planning of their businesses (c.f., e.g., Cooper, Woo, and Dunkelberg (1989), Cooper, Gimeno-Gascon, and Woo (1994), Vivarelli (1991), Storey (1994), Cressy (2006), Colombo, Delmastro, and Grilli (2004)). We asked in particular whether the persons had gathered working experience in the segment in which the business had been launched. We found that for almost all subgroups (except for male SUS start-ups) working experience had a significantly positive impact. Our observation underlines that it is important for the survival of a self-employed person to have gathered working experience not only in terms of years (as we showed before), but also in the specific business segment where the self-employment activity is planned. A change of the business segment may decrease the probability of success.

Interestingly, for the SUS support scheme no further preparation activities or specific motivations of the business founders had any significantly positive impact on their survival. With respect to the BA start-ups we found that the often mentioned 'push' and 'pull' factors have the expected impact on survival. For male founders the "pull' factor of "being my own boss"

\footnotetext{
${ }^{19}$ It should also be mentioned that this observation does not allow for the simple conclusion that simply investing more capital into a business automatically increases its survival probability.
} 
and for female founders the factor of having spotted a market gap increased their survival probability, while for both subgroups the 'push' factor "termination of unemployment" significantly decreased the survival probability. Another important negative effect was found for all male founders, irrespective of their programme choice: those who started their self-employment activities on the basis of "advice from the labor agency" had lower survival rates. This observation clearly indicates that the unemployment agency should not get involved in such decisions; it is essential that this significant decision is made by the business founder himself.

Finally, focusing on the preparation activities, we found, only for BA business founders, two variables with a significant impact. For male business founders it was observed that making use of a coach or a consultant positively affected the survival probability. Besides, we also found one counterintuitive result: having consulted potential customers before launching the business decreases the survival probability of BA-start-ups. From our perspective, this observation may be indicative of the founders having drawn wrong conclusions from their own surveys; they might have believed that their products will be self-sellers, without any further marketing effort, as potential customers might have indicated that they were interested in their products. However, our interpretation is purely speculative. Nevertheless, our result makes it clear that a market analysis alone, before a business is launched, is no guarantee for the success of the business idea. $^{20}$

\subsection{Direct Employment Effects}

Besides creating a job for the self-employed persons themselves, public authorities usually tie the start-up subsidies with the hope for further direct job creation. ${ }^{21}$ If they do create further jobs, it implies a 'double dividend' since the supported individuals not only end their own unemployment but also create additional jobs with recurring benefits.

\section{INSERT TABLE 8 ABOUT HERE}

Earlier empirical evidence available on the number of direct jobs created by start-ups varies widely. Most importantly, as already mentioned in Section 2, there has been a clear trend, according to which the absolute number of entrepreneurs with further employees has been constant in the last 15 years, while the number of sole entrepreneurs is growing consistently. In line with this trend the micro-census revealed that the share of start-ups with further employees

\footnotetext{
${ }^{20}$ The result might also be explained by findings of Köllinger, Minniti, and Schade (2005) who showed that business founders are not immune to overconfidence when they base their decision of becoming self-employed only on a self-assessment.

${ }^{21}$ We are fully aware that direct employment effects are only one part of all effects of newly created businesses. For further analysis of indirect positive and negative effects in case of Germany, see Fritsch and Mueller (2008), who identified an s-shaped employment effect of newly formed businesses. See also Fritsch (2008) for an overview of similar analysis conducted for various other countries. However, the aim of our study is different. We primarily aim to analyze to what extent start-ups by unemployed persons create further jobs, if at all.
} 
dropped from $30 \%$ to $20 \%$ during the last decade. Unfortunately this data source does not give information about the number of persons employed by the entrepreneurs. ${ }^{22}$

Table 8 shows the share of start-ups with at least one employee at the time of the interview. Figures for all the four groups are clearly varying. While $33 \%(26 \%)$ of the men (women) in BA already have at least one employee, this is true for only $14 \%(9 \%)$ of the men (women) in SUS. More of the BA start-ups have employees and the number of persons employed by them is higher than the average, which is around four. Hence, as a first conclusion, we can state that direct employment effects of the BA are on a similar level as for other start-ups mostly coming out of an employed status (compared to the KfW survey of the same year). In contrast to the $\mathrm{BA}$, direct employment effects of individuals using the SUS were rather small. ${ }^{23}$

In our survey, we also aimed to find out whether the solo entrepreneurs would like to employ further persons in the future or whether they rule out this possibility, irrespective of the future development of their business. We observe that most of the individuals who did not have employees at the time of the interview do neither plan to have any in the future, even if the business grows. For instance, $58 \%$ of women in SUS do not want employees 'by any means'. Including the $27 \%$ who answer 'rather no', $85 \%$ of the start-ups will probably not offer significant job creation in the future. Thus, most of the solo entrepreneurs deliberately aim to stay selfemployed without any further staff, indicating that the trend towards solo-entrepreneurship, which came up in the last 15 years (see section 2.2), is likely to continue in the future. On the other end, $42 \%$ of the male participants receving BA answer 'yes' (or 'rather yes'), indicating that some further direct job creation effects might be possible. Clearly, this is speculation at this point of time and needs to be verified. Last but not the least, when comparing the employment effects in Table 8 after 1.5 and 2.5 years, it is interesting to note that the crucial decision whether further persons will be employed in a newly found business seems to have been made relatively early in the lifetime of a small business. With the exception of male SUS start-ups, additional job creation in the second year was positive but relatively low. ${ }^{24}$

\footnotetext{
${ }^{22}$ There are several other sources providing such information. However, the share of sole entrepreneurs is underrepresented in most of them as there have been regular reports of the share of start-ups with further employees being higher than what is reported in the micro-census. For instance, Hinz and Jungbauer-Gans (1999) report that in 1996 only $53 \%$ among the formerly employed and $76 \%$ among the formerly unemployed founders were sole entrepreneurs, while the micro-census reported that $70 \%$ of start-ups did not have any further employees. Later on, KfW (2004 and 2005) states for the years 2003 and 2004 that $27 \%$ of the start-ups by previously unemployed persons offered, on average, two additional full-time jobs, while $53 \%$ of all young entrepreneurs offered four additional full-time jobs. For the year $2005 \mathrm{KfW}$ (2006) reports that $30 \%$ of all start-ups offered 2.8 full-time jobs to other persons. During the same period (between 2003 and 2005) the micro-census speaks of only around $20 \%$ of start-ups having created further jobs.

${ }^{23} \mathrm{It}$ is worth mentioning that start-ups usually pay lower wages to their employees than well established firms. Nevertheless, these employees appear to be more satisfied, cf., Winter-Ebmer and Zweimüller (1999) for Swiss and Brixy, Kohaut, and Schnabel (2007) for German data.

${ }^{24}$ The last observation corresponds, to a certain extent, to the findings of a long-term analysis conducted by Fritsch and Weyh (2006) over 18 years. They conclude (see Fritsch and Weyh, 2006, p.256) that "newly established businesses tend to start with growing employment, but after one or two years employment tends to be stagnant, or to decline".
} 


\subsection{Income}

As BA-supported business founders invested more capital and employed more persons than SUSsupported businesses, we also aimed to find out whether these activities paid in terms of higher incomes for BA start-ups. Table 9 reveals that this is true. Income relations are the same as the relations of invested capital and of direct employment effects. This means that BA-supported male business founders earned the highest income: their average net monthly income was around $2,350 €$, certainly a remarkable amount. They were followed by female BA-start-ups, who earned an average of $600 €$ less per month than their male counterparts. The income of SUS-start-ups was around $1,000 €$ for women and a little less than $1,500 €$ for men.

Clearly, these incomes can not be directly compared since the individual characteristics of the founders differ significantly. Therefore, we compare self-employment incomes of individuals with their previous income (when they were employed). Table 9 again reveals that the mean net income of all subgroups was higher from self-employment activity than under their previous employed positions (differences in incomes were between $135 €$ per month for female SUS startups and almost $500 €$ per month for male BA start-ups). ${ }^{25}$ Additionally, we calculated the median income and found out that it was still higher for men (between $160 €$ and $170 €$ ) and that around $55 \%$ of them earned more than in their last position as an employee. The opposite is true for female business founders: here, the median income was equal to the last income as an employee for the BA start-ups and it was $140 €$ less for SUS start-ups. Accordingly, only $45 \%$ of female SUS start-ups earned more as self-employed persons, indicating that there were few female start-ups whose income was significantly above the average in $2005 .^{26}$

As questions related to incomes are sensitive, we cross-checked the answers. We also asked the start-ups in the survey of 2005 how their actual income in 2004 (in their first year of selfemployment) compared with their income in the previous year, i.e. 2003 (when most of them were still employed); we asked them in the 2006 survey once again how their actual income in 2005 (in their second year of self-employment) compared with their income from the first year of self-employment (in 2004). We have calculated, in Table 9, the shares of all possible parameter variations and have found support for the distributions of incomes calculated earlier. For instance, $45 \%$ of male start-ups supported with BA reported to have earned less income in 2005 (compared to 2003). ${ }^{27}$ The calculation of the median indicated that $55 \%$ earned more in 2005 than in 2003.

The complete overview of incomes earned in self-employment tells us that the majority of the

\footnotetext{
${ }^{25}$ It should also be highlighted that the relative increase in income is higher for male participants in SUS compared to male participants in BA.

${ }^{26}$ Interestingly, there has not been much research on this question; the existing research shows that there are mixed findings with respect to the comparison of the income generated by self-employed persons in relation to the income of wage earners with similar characteristics. Hamilton (2000) showed that entrepreneurs "have both lower initial earnings and lower earnings growth than in paid employment". In contrast to this, Rosen and Willen (2002) and Fairlie (2005) find that entrepreneurs have higher mean and median income levels than employed persons.

${ }^{27}$ To be more specific, $19.1 \%$ report that the income had declined in 2004 and $2005,21.0 \%$ report a decline in 2004 and a constant level in 2005, and 4.8\% report to have earned the same in 2004 as in 2003, but less in 2005 .
} 
persons are not doing worse than before, when they worked as employees. Thus, a long existing prejudice that start-ups by unemployed persons are generating rather tiny incomes needs to be revised. We do not find evidence for this prejudice in our data when we focus on incomes 2.5 years after businesses were launched.

\section{INSERT TABLE 9 ABOUT HERE}

A different picture emerges when one only looks at incomes generated in the first year when the businesses were freshly launched. As we mentioned in Section 2.1, incomes at the beginning of self-employment activities are expected to be relatively low. Our dynamic analysis of incomes of the supported start-ups underpins this expectation. As Table 9 shows, between $60 \%$ (of male start-ups) and $70 \%$ (of female start-ups) declared that their income in 2004 was lower, or even much lower, than in 2003.

This observation makes it clear that instruments such as the BA or the SUS are essential to support start-ups during their initial periods when incomes are traditionally low. Having said that, we are discussing the possible occurrence of deadweight losses in the next Section.

\subsection{Deadweight Losses}

When effects of start-up subsidies are discussed, one of the key issues is the possible occurrence of deadweight losses. The definition of a deadweight loss in the context of start-up subsidies is - compared to other labour market policies such as wage subsidies — not so straightforward. If an employer hires an unemployed person whose wage is subsidized but would have hired this unemployed anyway, we talk about a deadweight loss. In the context of the start-up subsidies this translates into the question whether the individuals would have founded the business even without a subsidy, and whether their success (or failure) would have had the same probabilities with and without the subsidy. ${ }^{28}$

\section{INSERT TABLE 10 ABOUt HERE}

To the best of our knowledge, there is no earlier empirical evidence on this question. As to the first part of the problem of deadweight losses (how many persons would have started the business without a subsidy), our survey (Table 10) revealed that in fact nearly $50 \%$ of the individuals using a BA would have done so, around $28 \%$ would have started on a smaller scale,

\footnotetext{
${ }^{28}$ The first part of the question is relatively easy to answer, the second part is not. For an answer on the latter question, a matching of similar start-ups by unemployed persons needs to be carried out, where the treatment group is supported with BA or SUS and the control group is not. In Germany, however, there is almost no unemployed person who started self-employment without one of the two support schemes; which is why such a matching was not possible. Other related matchings in this research area which are, however, not apt to answer this particular question, were done by Pfeiffer and Reize (2000), who compared start-ups by unemployed persons with other start-ups, and by Baumgartner and Caliendo (2007), who compared start-ups by unemployed persons with a control group of other unemployed persons who were looking for other employment opportunities.
} 
and only $23 \%$ would not have started at all. It is interesting to note that there are no significant differences between men and women regarding this question. Things look a bit different for the SUS, where for both men and women the answers are about equally divided between the three questions. Hence, possible deadweight losses seem to be smaller here. Nevertheless, this observation should be interpreted very carefully, as we are not able to answer the question whether the businesses would have been successful, if these particular start-ups had not been supported by either of the two support schemes. And the relatively low incomes generated during the first year of self-employment (see Table 9) make it clear that the survival rates of these start-ups might have been lower, had the financial support not been granted.

It has also been feared that some of the start-ups were mainly motivated by the fear of running out of unemployment benefits. Looking at the remaining benefit entitlement (see Table 10) shows, however, that this is, if at all, only a problem for the SUS, because the participants here have only about five months left.

The last thing to note, when discussing possible deadweight losses, are the findings by Caliendo and Steiner (2007). They conduct a cost-benefit analysis and show that the bridging allowance is not only an effective but also an efficient programme (from the viewpoint of the FEA). By comparing the direct costs of the programme (for the FEA) and the direct benefits (in terms of saved unemployment benefit payments) it provides, it turns out that the FEA actually saves money by assisting people under this programme. Hence, the possible occurrence of deadweight losses does not seem to be a major issue. Things look different once again for the SUS, where the monetary efficiency for the FEA is negative.

\section{Conclusion and Outlook}

Empirical findings on the characteristics of unemployed business founders, their survival rates, direct job creation and other key variables are rather scarce. This might be because of two reasons. One is that start-up subsidies are usually one small component in the larger menu of active labour market policies of different countries. On the other hand, previously unemployed start-ups are often viewed as less serious business founders as they are "born out of necessity". In this respect, the German government made, in the beginning of this decade, a significant change: it eased the access to its existing instrument, the bridging allowance (BA), and it implemented in 2003 a second instrument, the start-up subsidy (SUS). Between 2003 and mid 2006, about one million previously unemployed persons took advantage of one of the two instruments. As a consequence, start-ups by unemployed persons started to play a major role in both, the labor market and the economic policy at large.

We base our analysis on a large representative data set which combines administrative data with survey data and contains information on 3,100 start-ups by unemployed persons set up in the year 2003. We follow individuals for about 2.5 years and are able to present detailed 
information on pre- and post-founding characteristics. Accordingly, our findings are, to the best of our knowledge, the first ones which allow to draw representative conclusions based on a large sample of start-ups by unemployed persons.

The main results of our analysis are: the two programmes - different in their designattracted different target groups. While the BA was used by persons whose characteristics are similar to the typical characteristics of all start-ups, the SUS was used by target groups under-represented in the population of typical business founders. Especially female and young male start-ups who were relatively less formally qualified (in terms of their highest school degree) felt attracted by the new programme.

Looking at the motivation for becoming self-employed, our research revealed a new phenomenon. While it is often believed that business founders who were unemployed before founding the business have to be treated at par with those setting up businesses out of necessity, we observed that almost half of the supported entrepreneurs were guided by both push and pull motives at the same time. Moreover, comparing the other pre-founding characteristics of SUS with BA start-ups, we observed that BA start-ups had gathered more experience from regular work in the segment where they wanted to launch their business and had made more efforts to prepare for their ventures.

Nevertheless, survival rates are relatively similar for the four subgroups and average out at about $70 \%{ }^{29}$ The just highlighted differences, however, affected the sizes of the created businesses. Male BA founders (followed by female BA founders, male SUS founders and female SUS founders) invested the highest amounts of capital, employed the highest number of additional employees, and consequently generated the highest incomes.

In this context, some further observations should be emphasized. First, the direct employment effects are of considerable significance for all business founders making use of the BA, while the vast majority of SUS start-ups said that they deliberately want to stay alone in their firm, even if their business allowed further job creation. This confirms a new trend of "soloentrepreneurship", observed in Germany for the last 15 years. Secondly, it is remarkable that the investment pattern differed among BA founders. Compared to males, female BA founders invested less during the start-up period but more after one or two years of running their own business successfully. Third, 2.5 years after the businesses were launched, the average (median) incomes were in all four subgroups (for the male entrepreneurs) above the average (median) income from their last employment activity. In contrast to this, in the first year of their selfemployment activity, between $60 \%$ and $70 \%$ of the start-ups explained that their income was below their last income as an employee, to a certain extent justifying the support from the BA and the SUS. The last result also shows - at least from an ex-post point of view - that the support from the SUS could have been restricted to a period shorter than three years. From an ex-ante point of view, however, we do not know whether the specific target groups, which felt

\footnotetext{
${ }^{29}$ Moreover, a considerable portion of persons who terminated their self-employment activities were able to return to regular employment.
} 
attracted by the current design of the SUS, would have considered self-employment as a serious opportunity if the support from the SUS had been restricted to one or two instead of three years.

Last but not the least, by making use of a duration model, we were able to analyse several variables driving the survival of the supported persons in self-employment. First and foremost, push and pull motives play a major role for previously unemployed business founders in the same way as for other start-ups, with pull motives increasing and push motives decreasing the survival probability. A careful preparation seems to pay (at least for male start-ups) when it is supported by third parties, such as coaches and consultants, while they should rather avoid simply following the advice from the local labour agency. Moreover, it is important to have gathered working experience for several years in the segment in which the business is launched. Higher amounts of capital invested in the business increase the survival probability. Higher school degrees and a favorable labour market history also had a positive impact on the survival rates for SUS business founders.

We conclude that both programmes, the BA and the SUS, worked in the intended way, indicating that two significantly different programmes supporting self-employment activities are worth considering if the two programmes are apt to attract a different clientele. According to our analysis, a considerable number of start-ups by unemployed persons are still self-employed 2.5 years after they launched their businesses (even if the empirical evidence is still preliminary for the SUS) and able to generate remarkable incomes. 


\section{References}

Andersson, P., And E. Wadensjö (2006): "Do the Unemployed Become Successful Entrepreneurs? A Comparison between the Unemployed, Inactive and Wage-Earners," Discussion Paper No. 2402, IZA, Bonn.

Audretsch, D., And M. Vivarelli (1995): "New Firm Formation in Italy," Economics Letters, 48, 77-81.

Bartelsmann, E., S. Scarpetta, and F. Schivardi (2005): "Comparative Analysis of Firm Demographics and Survival: Evidence from Micro-level Sources in OECD Countries," Industrial and Corporate Change, 14, 365-391.

Baumgartner, H., and M. Caliendo (2007): "Turning Unemployment into SelfEmployment: Effectiveness and Efficiency of Two Start-Up Programmes," IZA Discussion Paper No. 2660, Bonn.

Blanchflower, D., AND A. Oswald (1998): "What makes an entrepreneur?," Journal of Labor Economics, 16, 26-60.

Blanchflower, D., And A. Oswald (2007): "What Makes a Young Entrepreneur?," Discussion Paper No. 3139, IZA, Bonn.

Brixy, U., S. Kohaut, and C. Schnabel (2007): "Do Newly Founded Firms Pay Lower Wages? First Evidence from Germany," Small Business Economics, 29, 161-171.

Caliendo, M., F. Fossen, and A. Kritikos (2006): "Risk Attitudes of Nascent Entrepreneurs: New Evidence from an Experimentally-Validated Survey," Discussion Paper No. 2168, IZA, forthcoming in: Small Business Economics.

Caliendo, M., and V. Steiner (2005): "Aktive Arbeitsmarktpolitik in Deutschland: Bestandsaufnahme und Bewertung der mikroökonomischen Evaluationsergebnisse," Zeitschrift für Arbeitsmarktforschung / Journal for Labour Market Research, 38(2-3), 396-418.

(2007): "Ich-AG und Überbrückungsgeld - Neue Ergebnisse bestätigen Erfolg," DIWWochenbericht, (3), 25-32.

Caliendo, M., V. Steiner, and H. Baumgartner (2006): "Mikroökonometrische Analysen," in Evaluation der Maßnahmen zur Umsetzung der Vorschläge der Hartz-Kommission: Wirksamkeit der Instrumente: Existenzgründungen (Modul 1e), ed. by Forschungsverbund IAB, DIW, SINUS, GfA, infas, pp. 201-255.

Carrasco, R. (1999): "Transitions to and from Self-Employment in Spain: An Empirical Analysis," Oxford Bulletin of Economics and Statistics, 61(3), 315-341.

Colombo, M., M. Delmastro, and L. Grilli (2004): "Entrepreneurs' Human Capital and Start-Up Size of New Technology-based Firms," International Journal of Industrial Organization, 22, 1183-1211.

Cooper, A., F. Gimeno-Gascon, and C. Woo (1994): "Initial Human Capital and Financial Capital as Predictors of New Venture Performance," Journal of Business Venturing, 9, 371396.

Cooper, A., C. Woo, and W. Dunkelberg (1989): "Entrepreneurship and the Initial Size of Firms," Journal of Business Venturing, 4, 317-332.

Cressy, R. (2006): "Why Do Most Firms Die Young?," Small Business Economics, 26, 103116.

Eichhorst, W., and K. Zimmermann (2007): "And Then There Were Four...How Many (and Which) Measures of Active Labor Market Policy Do We Still Need?," Applied Economics Quarterly, 53(3), 243-272. 
Evans, L., And L. Leighton (1990): "Small Business Formation by Unemployed and Employed Workers," Small Business Economics, 2, 319-330.

FAIRlie, R. (2005): "Entrepreneurship and Earnings among Young Adults from Disadvantaged Families," Small Business Economics, 25, 351-382.

Fritsch, M. (2004): "Entrepreneurship, Entry and Performance of New Businesses Compared in Two Growth Regimes: East and West Germany," Journal of Evolutionary Economics, 14, $525-542$.

(2008): "How does New Business Development Affect Regional Development? Introduction to the Special Issue," Small Business Economics, forthcoming.

Fritsch, M., R. Grotz, U. Brixy, M. Niese, and A. Otto (2002): "Die statistische Erfassung von Gründungen in Deutschland - ein Vergleich von Beschäftigtenstatistik, Gewerbeanzeigenstatistik und den Mannheimer Gründungspanels," Allgemeines Statistisches Archiv, 86, 87-96.

Fritsch, M., And P. Mueller (2008): "The Effect of New Business Formation on Regional Development over Time: the Case of Germany," Small Business Economics, forthcoming.

Fritsch, M., And A. Weyh (2006): "How Large are the Direct Employment Effects of New Businesses? An Empirical Investigation for West Germany," Small Business Economics, 27, 245-260.

Hamilton, B. (2000): "Does Entrepreneurship Pay? An Empirical Analysis of the Returns to Self-Employment," Journal of Political Economy, 108(3), 604-631.

Hinz, T., And M. Jungbauer-Gans (1999): "Starting a Business after Unemployment: Characteristics and Chances of Success (Empirical Evidence from a Regional German Labour Market)," Entrepreneurship and Regional Develoment, 11, 317-333.

Institut Für Mittelstandsforschung (2007): "Newsletter 1/2007," Bonn.

Johannson, E. (2000): "Self-Employment and Liquidity Constraints - Evidence from Finland," Scandinavian Journal of Economics, 102, 123-134.

Köllinger, P., M. Minniti, and C. Schade (2005): "'I think I can, I think I can": Overconfidence and Entrepreneurial Behavior," Discussion Paper 501, DIW.

Koch, S., And F. Wiessner (2003): "Wer die Wahl hat, hat die Qual," IAB Kurzbericht, (2).

Kreditanstalt für Wiederaufbau (2004): "KfW-Gründungsmonitor 2004. Jährliche Analyse von Struktur und Dynamik des Gründungsgeschehens in Deutschland," Frankfurt.

(2005): "KfW-Gründungsmonitor 2005. Jährliche Analyse von Struktur und Dynamik des Gründungsgeschehens in Deutschland," Frankfurt.

(2006): "KfW-Gründungsmonitor 2005. Jährliche Analyse von Struktur und Dynamik des Gründungsgeschehens in Deutschland," Frankfurt.

Kritikos, A., And K. Kahle (2006): "Das Gründungsgeschehen in Deutschland," in Evaluation der Maßnahmen zur Umsetzung der Vorschläge der Hartz-Komission. Wirksamkeit der Instrumente: Existenzgründungen (Modul 1e), ed. by IAB, DIW, Sinus, GfA, infas, pp. 40-90. BMAS, Berlin.

Kronthaler, F. (2005): "Economic Capability of East German Regions: Results of a Cluster Analysis," Regional Studies, 39, 739-750.

Levenson, A., and K. Willard (2000): "Do firms get the financing they want?," Small Business Economics, 14, 83-94.

Meager, N. (1992): "Does Unemployment lead to Self-Employment," Small Business Economics, 4, 87-103. 
Meyer, B. (1990): "Unemployment Insurance and Unemployment Spells," Econometrica, 58, 757-782.

Narendranathan, W., and M. B. Stewart (1993): "How does the benefit effect vary as unemployment spells lengthen?," Journal of Applied Econometrics, 8, 361-381.

Parker, S., And M. van PraAg (2006): "Schooling, Capital Constraints and Entrepreneurial Performance: The Endogenous Triangle," forthcoming in: Journal of Business and Economic Statistics.

Pfeiffer, F., and F. Reize (2000): "Business Start-Ups by the Unemployed - an Econometric Analysis Based on Firm Data," Labour Economics, 7, 629-663.

Piorkowsky, M.-B. (2006): "Existenzgründungen im Kontext der Arbeits- und Lebensverhältnisse in Deutschland - Eine Strukturanalyse von Mikrozensusergebnissen," Discussion paper, Statistisches Bundesamt, Wiesbaden.

Rosen, H., And P. Willen (2002): "Risk, Return and Self-employment," Discussion Paper, University of Princeton.

Statistisches Bundesamt (2005): "Fachserie 1, Reihe 4.1.2.," Wiesbaden.

Storey, D. (1991): "The Birth of New Firms - Does Unemployment Matter? A Review of the Evidence," Small Business Economics, 3, 167-178. (1994): Understanding the Small Business Sector. Routledge, London.

Storey, D., And A. Jones (1987): "New Firm Formation - A Labor Market Approach to Industrial Entry," Scottish Journal of Political Economy, 34, 37-51.

van Praag, C., And P. Versloot (2007): "What Is the Value of Entrepreneurship? A Review of Recent Research," Small Business Economics, 29(3014), 351-382.

Vivarelli, M. (1991): "The Birth of New Enterprises," Small Business Economics, 3, 215-223.

Wagner, J. (2007): "What a Difference a Y makes - Female and Male Nascent Entrepreneurs in Germany," Small Business Economics, 28, 1-21.

Wiessner, F. (2001): Arbeitslose werden Unternehmer. Beiträge zur Arbeitsmarkt- und Berufsforschung, Nuremberg.

Winter-Ebmer, R., and J. Zweimüller (1999): "Firm-Size Wage Differentials in Switzerland: Evidence from Job-Changers," American Economic Review, Papers and Proceedings, 89, 89-93. 


\section{Tables and Figures}

Table 1: Design of the Programmes

\begin{tabular}{|c|c|c|}
\hline & Bridging Allowance & Start-Up Subsidy \\
\hline $\begin{array}{l}\text { Entry condi- } \\
\text { tions: }\end{array}$ & $\begin{array}{l}\text { Unemployment benefit entitlement } \\
\text { Approval of the business plan by an } \\
\text { external source (e.g. chamber of com- } \\
\text { merce) }\end{array}$ & $\begin{array}{l}\text { Unemployment benefit receipt } \\
\text { Approval of the business required as of } \\
\text { November } 2004\end{array}$ \\
\hline Support: & $\begin{array}{l}\text { Participant receives UB for six months } \\
\text { To cover social security liabilities, an } \\
\text { additional lump sum of approx. } 70 \% \\
\text { is granted }\end{array}$ & $\begin{array}{l}\text { Participants receive a fixed sum } \\
\text { of } € 600 / \text { month in the first year, } \\
€ 360 / \text { month (€240/month) in the } \\
\text { second (third) year } \\
\text { Claim has to be renewed every year, in- } \\
\text { come is not allowed to exceed } € 25,000 \\
\text { per year }\end{array}$ \\
\hline Other: & $\begin{array}{l}\text { Social security is left at the individual's } \\
\text { discretion }\end{array}$ & $\begin{array}{l}\text { Participants are required to join the } \\
\text { statutory pension insurance and receive } \\
\text { a reduced rate on the statutory health } \\
\text { insurance }\end{array}$ \\
\hline Details: & $\S 57(1)$ Social Code III. & $\S 421$ l Social Code III. \\
\hline
\end{tabular}

Table 2: Socio-Demographic Background of the Business Founders ${ }^{1}$

\begin{tabular}{lccccccccc}
\hline \hline & \multicolumn{2}{c}{$\begin{array}{c}\text { Start-Up } \\
\text { Subsidy }\end{array}$} & \multicolumn{3}{c}{ Bridging } & \multicolumn{4}{c}{ t-tests of } \\
& Men & Women & Men & Women & $p_{1}$ & $p_{2}$ & $p_{3}$ & $p_{4}$ \\
\hline Married & 0.452 & 0.582 & 0.631 & 0.432 & 0.000 & 0.000 & 0.000 & 0.000 \\
Health restrictions & 0.089 & 0.044 & 0.040 & 0.034 & 0.634 & 0.001 & 0.000 & 0.444 \\
German & 0.338 & 0.295 & 0.286 & 0.241 & 0.087 & 0.077 & 0.013 & 0.055 \\
Desired working time: Full-Time & 0.979 & 0.550 & 0.993 & 0.833 & 0.000 & 0.000 & 0.004 & 0.000 \\
Children & 0.270 & 0.521 & 0.387 & 0.299 & 0.002 & 0.000 & 0.000 & 0.000 \\
Age (in years) & 37.7 & 39.2 & 39.4 & 39.4 & 0.918 & 0.001 & 0.000 & 0.781 \\
Age category & & & & & & & & \\
$\quad$ 18-29 years & 0.239 & 0.131 & 0.135 & 0.111 & 0.226 & 0.000 & 0.000 & 0.000 \\
30-39 years & 0.339 & 0.393 & 0.381 & 0.429 & 0.099 & 0.028 & 0.054 & 0.352 \\
$\quad$ 40-49 years & 0.281 & 0.352 & 0.353 & 0.325 & 0.326 & 0.003 & 0.001 & 0.375 \\
$\quad$ 50-64 years & 0.141 & 0.124 & 0.131 & 0.135 & 0.840 & 0.331 & 0.533 & 0.594 \\
\hline Observations & 811 & 704 & 1,207 & 378 & & & & \\
\hline \hline
\end{tabular}

${ }^{1}$ Characteristics are measured at the beginning of the start-up. Numbers are shares unless stated otherwise.

${ }^{2} p$-values refer to t-tests of mean equality in the variables between men and women in BA $\left(p_{1}\right)$, men and women in SUS $\left(p_{2}\right)$, men in BA and SUS $\left(p_{3}\right)$ as well as women in BA and SUS $\left(p_{4}\right)$. 
Table 3: Qualification and Labor Market History of the Business Founders ${ }^{1}$

\begin{tabular}{lcccccccccc}
\hline \hline & \multicolumn{2}{c}{$\begin{array}{c}\text { Start-Up } \\
\text { Subsidy }\end{array}$} & \multicolumn{3}{c}{ Bridging } & \multicolumn{4}{c}{ t-tests of } \\
& Men & Women & Men & Women & $p_{1}$ & $p_{2}$ & $p_{3}$ & $p_{4}$ \\
\hline School degree & & & & & & & & \\
$\quad$ No/Low degree & 0.475 & 0.310 & 0.324 & 0.164 & 0.000 & 0.000 & 0.000 & 0.000 \\
$\quad$ Middle secondary degree & 0.237 & 0.335 & 0.239 & 0.278 & 0.124 & 0.000 & 0.923 & 0.053 \\
$\quad$ Upper secondary schooling & 0.289 & 0.355 & 0.437 & 0.558 & 0.000 & 0.006 & 0.000 & 0.000 \\
Unemployment benefits (in $€$ ) & 23.33 & 17.25 & 38.82 & 29.76 & 0.000 & 0.000 & 0.000 & 0.000 \\
Remaining benefit entitlement (in months) & 4.72 & 5.02 & 7.31 & 6.83 & 0.184 & 0.304 & 0.000 & 0.000 \\
Duration of last unemployment & & & & & & & & \\
$\quad$ 3 months & 0.300 & 0.341 & 0.321 & 0.325 & 0.863 & 0.086 & 0.318 & 0.607 \\
$\quad 3$ months - < 6 months & 0.207 & 0.156 & 0.239 & 0.206 & 0.183 & 0.011 & 0.089 & 0.038 \\
$\quad$ months - < 1 year & 0.284 & 0.344 & 0.314 & 0.352 & 0.170 & 0.012 & 0.145 & 0.790 \\
$\quad$ year - < 2 years & 0.210 & 0.159 & 0.126 & 0.116 & 0.624 & 0.012 & 0.000 & 0.057 \\
\hline \hline
\end{tabular}

${ }^{1}$ Characteristics are measured at the beginning of the start-up. Numbers are shares unless stated otherwise.

${ }^{2} p$-values refer to t-tests of mean equality in the variables between men and women in BA $\left(p_{1}\right)$, men and women in SUS $\left(p_{2}\right)$, men in BA and SUS $\left(p_{3}\right)$ as well as women in BA and SUS $\left(p_{4}\right)$.

Table 4: Experience, Preparation, Motivation, and Risk-Aversion ${ }^{1}$

\begin{tabular}{|c|c|c|c|c|c|c|c|c|}
\hline & \multicolumn{2}{|c|}{$\begin{array}{l}\text { Start-Up } \\
\text { Subsidy }\end{array}$} & \multicolumn{2}{|c|}{$\begin{array}{l}\text { Bridging } \\
\text { Allowance }\end{array}$} & \multicolumn{4}{|c|}{$\begin{array}{c}\text { t-tests of } \\
\text { Mean Equality }\end{array}$} \\
\hline & Men & Women & Men & Women & $p_{1}$ & $p_{2}$ & $p_{3}$ & $p_{4}$ \\
\hline \multicolumn{9}{|l|}{ Experience before start-up } \\
\hline Yes, from regular work & 0.633 & 0.543 & 0.727 & 0.728 & 0.972 & 0.000 & 0.000 & 0.000 \\
\hline Yes, from secondary work & 0.279 & 0.264 & 0.204 & 0.243 & 0.101 & 0.528 & 0.000 & 0.455 \\
\hline Yes, from leisure time & 0.359 & 0.338 & 0.260 & 0.230 & 0.242 & 0.398 & 0.000 & 0.000 \\
\hline No & 0.132 & 0.193 & 0.131 & 0.130 & 0.949 & 0.001 & 0.946 & 0.008 \\
\hline \multicolumn{9}{|l|}{ Preparation for start-up } \\
\hline Self-consulted potential costumers & 0.470 & 0.440 & 0.496 & 0.431 & 0.027 & 0.251 & 0.243 & 0.773 \\
\hline of informative meetings & 0.372 & 0.500 & 0.511 & 0.622 & 0.000 & 0.000 & 0.000 & 0.000 \\
\hline Use of coaching and consulting & 0.190 & 0.266 & 0.330 & 0.442 & 0.000 & 0.000 & 0.000 & 0.000 \\
\hline Support by others & 0.390 & 0.428 & 0.599 & 0.566 & 0.257 & 0.134 & 0.000 & 0.000 \\
\hline No certain preparation & 0.147 & 0.125 & 0.077 & 0.082 & 0.754 & 0.220 & 0.000 & 0.031 \\
\hline \multicolumn{9}{|l|}{ Motives for start-up } \\
\hline I always wanted to be $n$ & 0.560 & 0.459 & 0.553 & 0.487 & 0.023 & 0.000 & 0.778 & 0.380 \\
\hline Termination of unemployment & 0.831 & 0.838 & 0.750 & 0.712 & 0.140 & 0.715 & 0.000 & 0.000 \\
\hline Exhaustion of unemployment benefit entitlement & 0.349 & 0.372 & 0.246 & 0.262 & 0.535 & 0.348 & 0.000 & 0.000 \\
\hline Advice from the labor agency & 0.179 & 0.234 & 0.122 & 0.164 & 0.034 & 0.007 & 0.000 & 0.007 \\
\hline I already had first customers & 0.650 & 0.570 & 0.601 & 0.598 & 0.901 & 0.001 & 0.028 & 0.369 \\
\hline I spotted a market gap & 0.279 & 0.385 & 0.313 & 0.333 & 0.463 & 0.000 & 0.097 & 0.093 \\
\hline Avoidance of regional mobility & 0.307 & 0.372 & 0.302 & 0.270 & 0.238 & 0.007 & 0.794 & 0.001 \\
\hline Push and pull-Motivation ${ }^{3}$ & 0.459 & 0.382 & 0.382 & 0.331 & 0.072 & 0.003 & 0.000 & 0.527 \\
\hline
\end{tabular}

${ }^{1}$ Characteristics are measured at the beginning of the start-up. Numbers are shares unless stated otherwise.

${ }^{2} p$-values refer to t-tests of mean equality in the variables between men and women in BA $\left(p_{1}\right)$, men and women in SUS $\left(p_{2}\right)$, men in BA and SUS $\left(p_{3}\right)$ as well as women in BA and SUS $\left(p_{4}\right)$.

${ }^{3}$ Individuals who answered 'I always wanted to be my own boss' and 'Termination of unemployment' simultaneously as motives for start-up. 
Table 5: Industry and Start-Up Capital of the Business ${ }^{1}$

\begin{tabular}{|c|c|c|c|c|c|c|c|c|}
\hline & \multicolumn{2}{|c|}{$\begin{array}{l}\text { Start-Up } \\
\text { Subsidy }\end{array}$} & \multicolumn{2}{|c|}{$\begin{array}{c}\text { Bridging } \\
\text { Allowance }\end{array}$} & \multicolumn{4}{|c|}{$\begin{array}{c}\text { t-tests of } \\
\text { Mean Equality }\end{array}$} \\
\hline & Men & Women & Men & Women & $p_{1}$ & $p_{2}$ & $p_{3}$ & $p_{4}$ \\
\hline \multicolumn{9}{|l|}{ Industry of start-up } \\
\hline Agriculture, forestry, fishery & 0.027 & 0.003 & 0.007 & 0.005 & 0.775 & 0.000 & 0.000 & 0.527 \\
\hline Crafts & 0.129 & 0.055 & 0.110 & 0.040 & 0.000 & 0.000 & 0.193 & 0.258 \\
\hline Construction & 0.125 & 0.023 & 0.122 & 0.029 & 0.000 & 0.000 & 0.865 & 0.522 \\
\hline Retail & 0.166 & 0.166 & 0.152 & 0.124 & 0.185 & 0.989 & 0.378 & 0.067 \\
\hline Transport, logistics & 0.049 & 0.016 & 0.035 & 0.021 & 0.184 & 0.000 & 0.107 & 0.509 \\
\hline Banking, insurance & 0.038 & 0.023 & 0.084 & 0.056 & 0.072 & 0.083 & 0.000 & 0.005 \\
\hline Information technology & 0.095 & 0.021 & 0.116 & 0.040 & 0.000 & 0.000 & 0.131 & 0.079 \\
\hline Other services & 0.305 & 0.607 & 0.296 & 0.587 & 0.000 & 0.000 & 0.690 & 0.539 \\
\hline Other industries & 0.065 & 0.087 & 0.078 & 0.098 & 0.221 & 0.117 & 0.284 & 0.540 \\
\hline \multicolumn{9}{|l|}{ Start-up capital } \\
\hline No start-up capital & 0.496 & 0.580 & 0.349 & 0.397 & 0.090 & 0.001 & 0.000 & 0.000 \\
\hline Up to 2,500 Euro & 0.137 & 0.155 & 0.078 & 0.116 & 0.020 & 0.323 & 0.000 & 0.084 \\
\hline Up to 10,000 Euro & 0.203 & 0.158 & 0.208 & 0.201 & 0.773 & 0.021 & 0.807 & 0.072 \\
\hline 10,000 Euro and more & 0.164 & 0.108 & 0.365 & 0.286 & 0.004 & 0.002 & 0.000 & 0.000 \\
\hline Share of own capital & 75.64 & 75.58 & 72.73 & 69.36 & 0.224 & 0.982 & 0.009 & 0.325 \\
\hline Amount of own capital (in $€$ ) & 6882.4 & 4382.8 & 13017.9 & 8730.5 & 0.050 & 0.000 & 0.004 & 0.103 \\
\hline Additional capital needed & 0.339 & 0.310 & 0.286 & 0.409 & 0.001 & 0.416 & 0.000 & 0.004 \\
\hline Financing further growth & 0.695 & 0.683 & 0.611 & 0.618 & 0.908 & 0.852 & 0.008 & 0.375 \\
\hline Financing of projects & 0.260 & 0.228 & 0.340 & 0.289 & 0.426 & 0.579 & 0.006 & 0.000 \\
\hline Replacement finance & 0.366 & 0.317 & 0.291 & 0.289 & 0.985 & 0.433 & 0.040 & 0.278 \\
\hline Emergency finance & 0.145 & 0.129 & 0.197 & 0.211 & 0.803 & 0.722 & 0.024 & 0.002 \\
\hline Other reasons & 0.069 & 0.158 & 0.108 & 0.132 & 0.590 & 0.029 & 0.752 & 0.012 \\
\hline
\end{tabular}

${ }^{1}$ Characteristics are measured at the beginning of the start-up. Numbers are shares unless stated otherwise.

${ }^{2} p$-values refer to t-tests of mean equality in the variables between men and women in BA $\left(p_{1}\right)$, men and women in SUS $\left(p_{2}\right)$, men in BA and SUS $\left(p_{3}\right)$ as well as women in BA and SUS $\left(p_{4}\right)$.

Table 6: Employment Status at Interview Month ${ }^{1}$

\begin{tabular}{|c|c|c|c|c|}
\hline & \multicolumn{2}{|c|}{$\begin{array}{c}\text { Start-Up } \\
\text { Subsidy }\end{array}$} & \multicolumn{2}{|c|}{$\begin{array}{l}\text { Bridging } \\
\text { Allowance }\end{array}$} \\
\hline & Men & Women & Men & Women \\
\hline Self-Employed & 68.8 & 73.4 & 71.0 & 66.7 \\
\hline Regular Employed ${ }^{(\mathrm{a})}$ & 11.0 & 7.7 & 13.2 & 16.7 \\
\hline Unemployed & 15.0 & 7.7 & 10.7 & 9.2 \\
\hline Other & 5.2 & 11.2 & 5.1 & 7.4 \\
\hline Permanently Self-Employed ${ }^{(\mathrm{b})}$ & 68.8 & 72.2 & 67.4 & 63.5 \\
\hline Observations & 811 & 704 & 1,207 & 378 \\
\hline \multicolumn{5}{|c|}{$\begin{array}{l}{ }^{1} \text { Interviews took place in January/February 2006, that is at least } 28 \text { months } \\
\text { after the businesses were founded. } \\
\text { (a) Includes 'Midi-Jobs' which are jobs in an income range between } € 401-800 \text {. } \\
\text { (b) Refers to individuals who have been permanently self-employed during the } \\
\text { observation period. }\end{array}$} \\
\hline
\end{tabular}


Table 7: Survival Analysis of Self-Employment Duration (PHM with unobserved heterogeneity) ${ }^{1}$

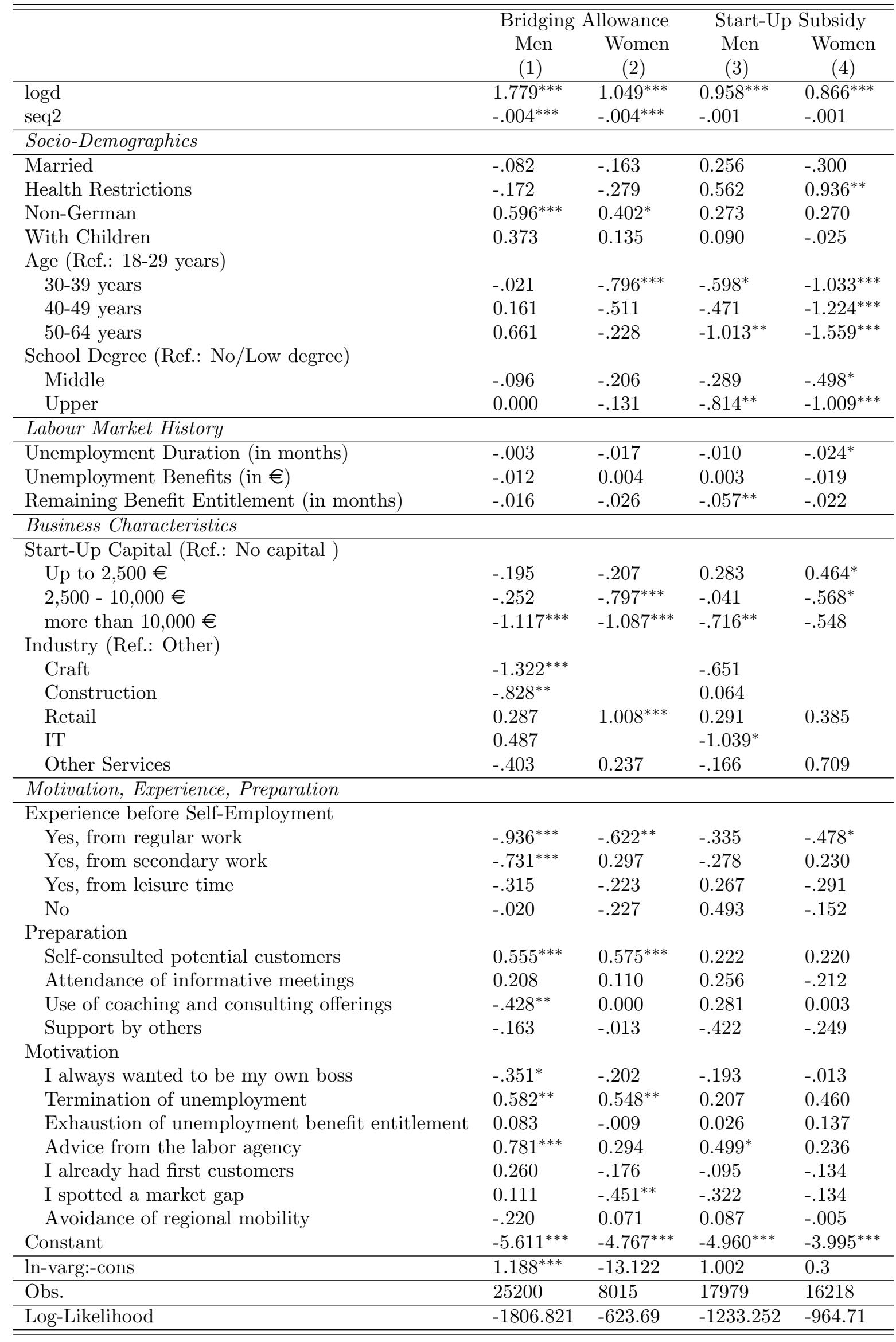

Note: Estimations are done using the pgmhaz8 Stata module. 
Table 8: Direct Employment Effects and Future Development ${ }^{1}$

\begin{tabular}{|c|c|c|c|c|c|c|c|c|}
\hline & \multicolumn{2}{|c|}{$\begin{array}{c}\text { Start-Up } \\
\text { Subsidy }\end{array}$} & \multicolumn{2}{|c|}{$\begin{array}{c}\text { Bridging } \\
\text { Allowance }\end{array}$} & \multicolumn{4}{|c|}{$\begin{array}{c}\text { t-tests of } \\
\text { Mean Equality }^{2}\end{array}$} \\
\hline & Men & Women & Men & Women & $p_{1}$ & $p_{2}$ & $p_{3}$ & $p_{4}$ \\
\hline \multicolumn{9}{|c|}{ First Interview after 16 months: } \\
\hline Start-ups with employees & 0.088 & 0.072 & 0.296 & 0.215 & 0.010 & 0.299 & 0.000 & 0.000 \\
\hline Number of employees & 2.28 & 2.10 & 3.83 & 3.51 & 0.737 & 0.712 & 0.007 & 0.000 \\
\hline Share of regular employees & 0.217 & 0.337 & 0.378 & 0.495 & 0.362 & 0.612 & 0.444 & 0.167 \\
\hline \multicolumn{9}{|c|}{ Second interview after 28 months: } \\
\hline Start-ups with employees & 0.145 & 0.094 & 0.329 & 0.256 & 0.025 & 0.009 & 0.000 & 0.000 \\
\hline Number of employees & 2.40 & 3.00 & 4.16 & 3.91 & 0.747 & 0.345 & 0.693 & 0.000 \\
\hline Share of regular employees & 0.218 & 0.165 & 0.367 & 0.283 & 0.147 & 0.413 & 0.137 & 0.000 \\
\hline \multicolumn{9}{|l|}{ Employees in the future? } \\
\hline Yes, surely & 0.066 & 0.047 & 0.113 & 0.031 & 0.001 & 0.195 & 0.008 & 0.375 \\
\hline Rather yes & 0.230 & 0.106 & 0.306 & 0.214 & 0.014 & 0.000 & 0.006 & 0.000 \\
\hline Rather no & 0.394 & 0.271 & 0.333 & 0.313 & 0.604 & 0.000 & 0.040 & 0.278 \\
\hline No, by no means & 0.311 & 0.577 & 0.248 & 0.443 & 0.000 & 0.000 & 0.024 & 0.002 \\
\hline
\end{tabular}

Table 9: Development of Income between 2003 and $2005^{1}$

\begin{tabular}{|c|c|c|c|c|c|c|c|c|}
\hline & \multicolumn{2}{|c|}{$\begin{array}{l}\text { Start-Up } \\
\text { Subsidy }\end{array}$} & \multicolumn{2}{|c|}{$\begin{array}{l}\text { Bridging } \\
\text { Allowance }\end{array}$} & \multicolumn{4}{|c|}{$\begin{array}{c}\text { t-tests of } \\
\text { Mean Equality }\end{array}$} \\
\hline & Men & Women & Men & Women & $p_{1}$ & $p_{2}$ & $p_{3}$ & $p_{4}$ \\
\hline \multicolumn{9}{|l|}{2004 vs. 2003: Lower } \\
\hline 2005 vs. 2004: Lower & 0.191 & 0.262 & 0.216 & 0.274 & 0.020 & 0.001 & 0.182 & 0.667 \\
\hline 2005 vs. 2004: Equal & 0.210 & 0.217 & 0.174 & 0.167 & 0.776 & 0.752 & 0.043 & 0.056 \\
\hline 2005 vs. 2004: Higher & 0.215 & 0.218 & 0.229 & 0.252 & 0.367 & 0.882 & 0.461 & 0.217 \\
\hline \multicolumn{9}{|l|}{2004 vs. 2003: Equal } \\
\hline 2005 vs. 2004: Lower & 0.048 & 0.028 & 0.044 & 0.025 & 0.100 & 0.051 & 0.636 & 0.723 \\
\hline 2005 vs. 2004: Equal & 0.062 & 0.069 & 0.065 & 0.066 & 0.952 & 0.622 & 0.822 & 0.854 \\
\hline 2005 vs. 2004: Higher & 0.061 & 0.058 & 0.078 & 0.085 & 0.685 & 0.824 & 0.145 & 0.103 \\
\hline \multicolumn{9}{|l|}{2004 vs. 2003: Higher } \\
\hline 2005 vs. 2004: Lower & 0.060 & 0.031 & 0.031 & 0.027 & 0.713 & 0.010 & 0.002 & 0.719 \\
\hline 2005 vs. 2004: Equal & 0.059 & 0.037 & 0.061 & 0.033 & 0.040 & 0.062 & 0.845 & 0.710 \\
\hline 2005 vs. 2004: Higher & 0.094 & 0.079 & 0.103 & 0.071 & 0.073 & 0.315 & 0.531 & 0.644 \\
\hline \multicolumn{9}{|c|}{ Monthly income at second interview } \\
\hline Income (in $€$ ) & 1445.48 & 949.40 & 2347.54 & 1764.68 & 0.000 & 0.000 & 0.000 & 0.000 \\
\hline \multicolumn{9}{|c|}{ Approximated income before unemployment } \\
\hline Monthly net income (in $€$ ) & 1076.72 & 862.61 & 1940.77 & 1487.89 & 0.000 & 0.000 & 0.000 & 0.000 \\
\hline \multicolumn{9}{|l|}{ Change in income } \\
\hline Mean difference (in €) & 370.21 & 135.86 & 497.94 & 390.86 & & & & \\
\hline Median difference (in $€$ ) & 161.53 & -138.46 & 172.30 & -1.92 & & & & \\
\hline Share with positive difference ${ }^{3}$ & 57.3 & 44.9 & 54.9 & 50.4 & & & & \\
\hline
\end{tabular}

\footnotetext{
1 Numbers are shares unless stated otherwise.

${ }^{2} p$-values refer to t-tests of mean equality in the variables between men and women in BA $\left(p_{1}\right)$, men and women in SUS $\left(p_{2}\right)$, men in BA and SUS $\left(p_{3}\right)$ as well as women in BA and SUS $\left(p_{4}\right)$.

${ }^{3}$ Share of individuals where income difference is positive.
} 
Table 10: Deadweight Losses ${ }^{1}$

\begin{tabular}{lccccccccc}
\hline \hline & \multicolumn{2}{c}{$\begin{array}{c}\text { Start-Up } \\
\text { Subsidy }\end{array}$} & \multicolumn{2}{c}{ Bridging } & \multicolumn{4}{c}{ t-tests of } \\
& Men & Women & Men & Women & $p_{1}$ & $p_{2}$ & $p_{3}$ & $p_{4}$ \\
\hline Remaining benefit entitlement (in months) & 4.716 & 5.018 & 7.314 & 6.828 & 0.184 & 0.304 & 0.000 & 0.000 \\
$\quad$ & & & & & & & & \\
$\quad$ Start-up without subsidy? & 0.369 & 0.314 & 0.469 & 0.471 & 0.947 & 0.025 & 0.000 & 0.000 \\
$\quad$ Yes & 0.319 & 0.312 & 0.285 & 0.278 & 0.814 & 0.761 & 0.100 & 0.258 \\
$\quad$ Yes, but on a smaller scale or later & 0.300 & 0.366 & 0.232 & 0.231 & 0.993 & 0.008 & 0.001 & 0.000 \\
$\quad$ No, by no means & & & & &
\end{tabular}

${ }^{1}$ Characteristics are measured at the beginning of the start-up. Numbers are shares unless stated otherwise.

${ }^{2} p$-values refer to t-tests of mean equality in the variables between men and women in BA $\left(p_{1}\right)$, men and women in SUS $\left(p_{2}\right)$, men in BA and SUS $\left(p_{3}\right)$ as well as women in BA and SUS $\left(p_{4}\right)$.

Figure 1: Entries in Start-Up Programs, 1994-2005 ${ }^{1}$

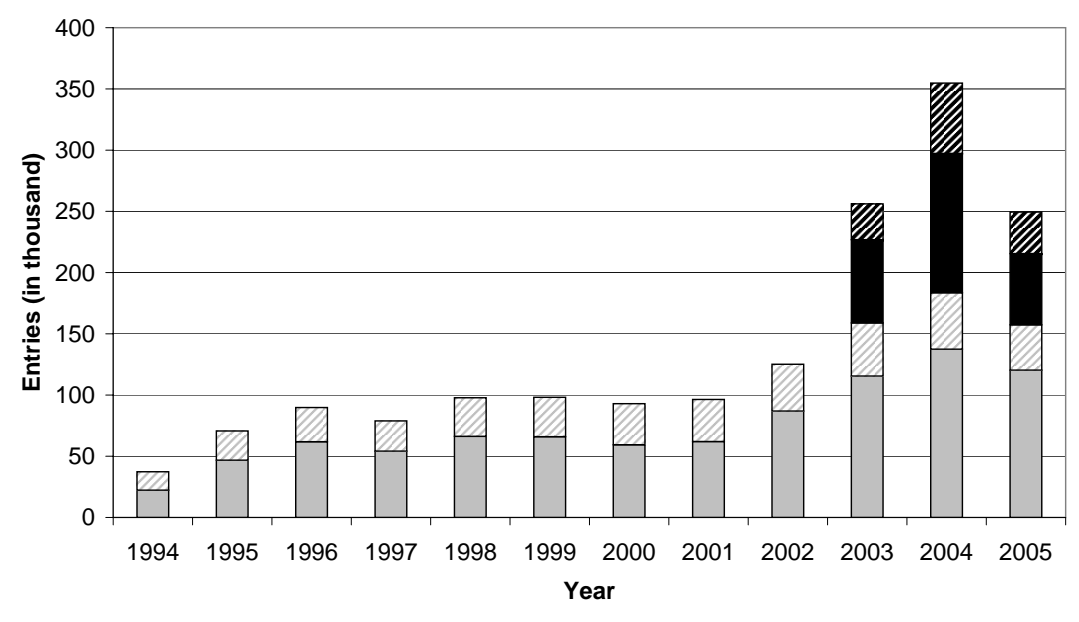

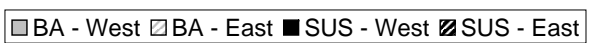

Note: BA: Bridging Allowance, SUS: Start-Up Subsidy 
Figure 2: Number of Self-Employed with/without Employees, Share of SelfEmployed $^{1}, 1991-2005$

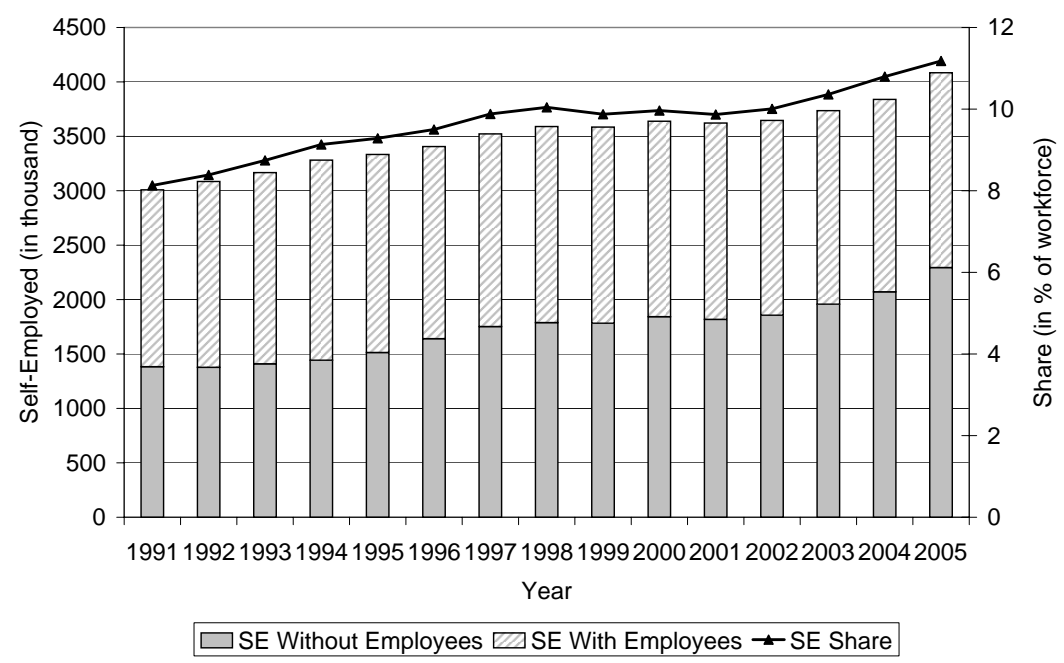

Source: Piorkowsky (2006)

${ }^{1}$ Share is calculated in relation to the total workforce.

Figure 3: Survival Rates in Self-Employment

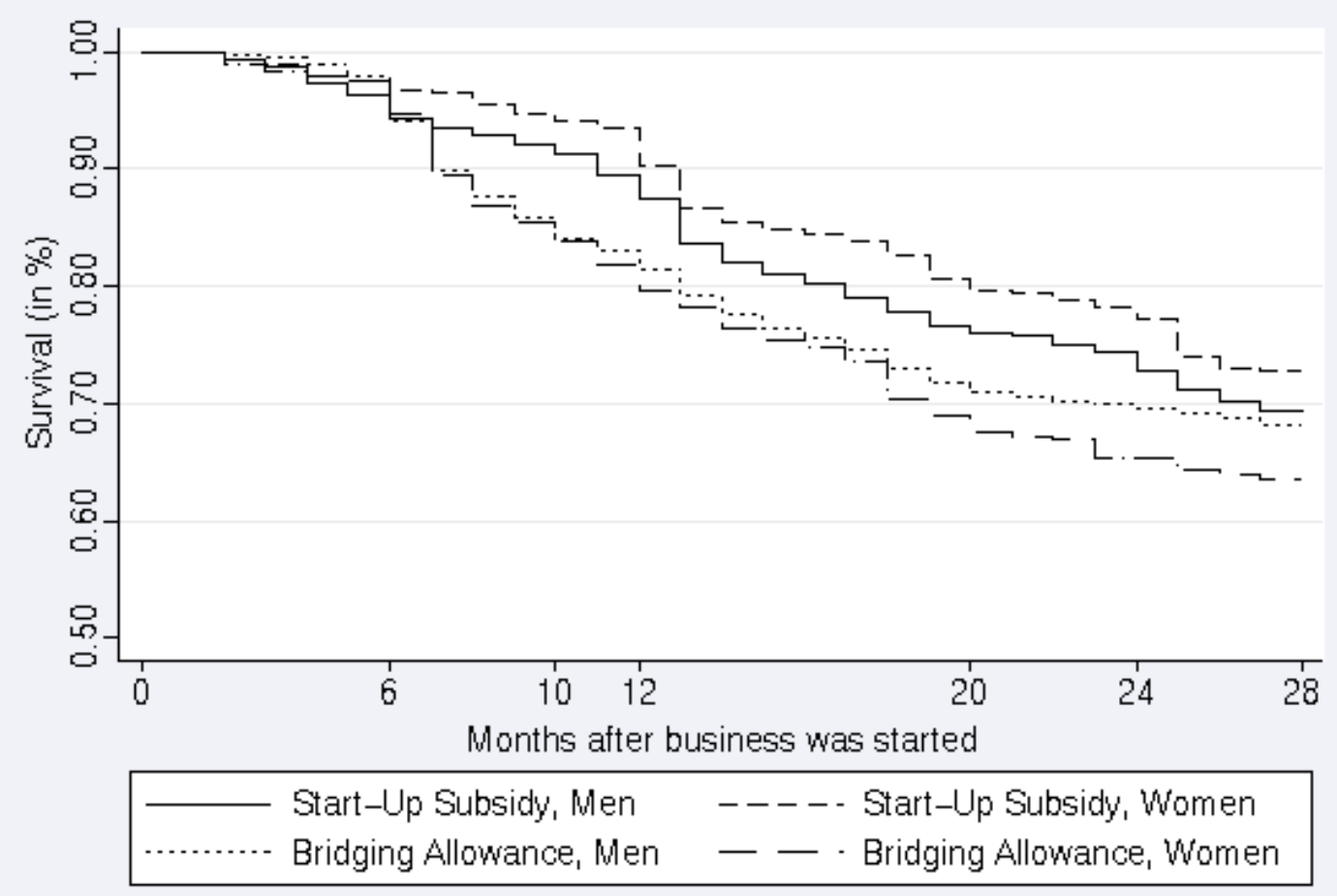

Source: Own calculations 